\title{
Glucosylceramide Synthase Is Involved in Development of Invariant Natural Killer T Cells
}

\section{OPEN ACCESS}

Edited by: Loretta Tuosto, Sapienza Università di Roma, Italy

Reviewed by: Giulia Casorati, San Raffaele Hospital (IRCCS), Italy Christian Kurts, University of Bonn, Germany

*Correspondence: Zoran V. Popovic

z.popovic@dkfz.de;

Stefan Porubsky

stefan.porubsky@umm.de

tPresent address: Stefan Porubsky, Institute of Pathology, University Medical Center Mannheim, University of Heidelberg, Mannheim, Germany

Specialty section: This article was submitted to T Cell Biology, a section of the journal Frontiers in Immunology

Received: 06 February 2017 Accepted: 05 July 2017

Published: 21 July 2017

Citation:

Popovic ZV, Rabionet $M$, Jennemann $R$, Krunic $D$, Sandhoff $R$, Gröne H-J and Porubsky S (2017)

Glucosylceramide Synthase Is Involved in Development of Invariant Natural Killer T Cells.

Front. Immunol. 8:848. doi: 10.3389/fimmu.2017.00848

\author{
Zoran V. Popovic ${ }^{1,2 *}$, Mariona Rabionet ${ }^{1}$, Richard Jennemann ${ }^{1}$, Damir Krunic ${ }^{3}$, \\ Roger Sandhoff', Hermann-Josef Gröne ${ }^{1}$ and Stefan Porubsky ${ }^{1 *+}$
}

${ }^{1}$ Cellular and Molecular Pathology, German Cancer Research Center, Heidelberg, Germany, ${ }^{2}$ Institute of Pathology, University Medical Center Mannheim, University of Heidelberg, Mannheim, Germany, ${ }^{3}$ Light Microscopy Facility, German Cancer Research Center, Heidelberg, Germany

Invariant natural killer T (iNKT) cells represent a unique population of CD1d-restricted $T$ lymphocytes expressing an invariant $T$ cell receptor encoded by $V_{\alpha} 14-J \alpha 18$ and Vo24-Ja18 gene segments in mice and humans, respectively. Recognition of CD1dloaded endogenous lipid antigen(s) on CD4/CD8-double positive (DP) thymocytes is essential for the development of iNKT cells. The lipid repertoire of DP thymocytes and the identity of the decisive endogenous lipid ligands have not yet been fully elucidated. Glycosphingolipids (GSL) were implicated to serve as endogenous ligands. However, further in vivo investigations were hampered by early embryonal lethality of mice deficient for the key GSL-synthesizing enzyme glucosylceramide (GlcCer) synthase [GlcCer synthase (GCS), EC 2.4.1.80]. We have now analyzed the GSL composition of DP thymocytes and shown that GlcCer represented the sole neutral GSL and the acidic fraction was composed of gangliosides. Furthermore, we report on a mouse model

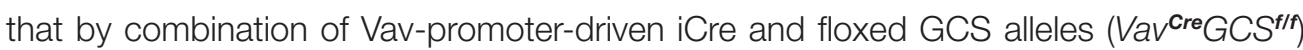
enabled an efficient depletion of GCS-derived GSL very early in the T cell development, reaching a reduction by $99.6 \%$ in DP thymocytes. Although the general T cell population remained unaffected by this depletion, iNKT cells were reduced by approximately $50 \%$ in thymus, spleen, and liver and showed a reduced proliferation and an increased apoptosis rate. The $\mathrm{V} \beta$-chains repertoire and development of iNKT cells remained unaltered. The GSL-depletion neither interfered with expression of CD1d, SLAM, and Ly108 molecules nor impeded the antigen presentation on DP thymocytes. These results indicate that GlcCer-derived GSL, in particular GlcCer, contribute to the homeostatic development of iNKT cells.

Keywords: CD1, glycosphingolipid, glucosylceramide, glucosylceramide synthase, natural killer T cell, thymus

\section{INTRODUCTION}

Natural killer T (NKT) cells represent a unique $\mathrm{T}$ cell population co-expressing NK cell markers such as NK1.1 (CD161) $(1,2)$. Initially, a subset of NKT cells bearing an invariant T cell receptor

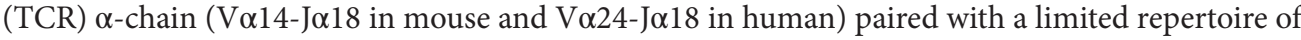
$\beta$-chains ( $\mathrm{V} \beta 2, \mathrm{~V} \beta 7, \mathrm{~V} \beta 8.2$ in mouse and $\mathrm{V} \beta 11$ in human) could be identified, hence the designation 
as invariant NKT cells [invariant natural killer T (iNKT) or type I NKT] (3-6). iNKT cells are important mediators of tumor surveillance, peripheral tolerance and antimicrobial defense (7-15).

In contrast to conventional T cells, iNKT cells recognize lipid antigens presented by non-polymorphic MHC class I-like CD1 molecules $(16,17)$. Human genome encodes for five CD1 molecules that-based on the amino acid sequence-can be assigned to either group I (CD1a, -b, -c, and -e) or group II (CD1d) (18). Mice lack group I CD1 molecules and have two group II Cd1 genes termed $C d 1 d 1$ and $C d 1 d 2$, from which only $C d 1 d 1$ seems to encode for a functional protein (19). Whereas presentation of peptide antigens on MHC molecules of thymic cortical epithelial cells is a prerequisite for the development of conventional T cells, positive selection of iNKT cells requires presentation of lipid antigens by $\mathrm{CD} 1$ molecules of double positive $\left(\mathrm{CD} 4^{+} / \mathrm{CD}^{+}\right)$thymocytes (20-22). In addition, lysosomal proteases and sphingolipid activator proteins, also known as saposins, are indispensable for normal thymic iNKT cell development suggesting that loading of lipid antigens onto CD1 molecules plays a crucial role in this process (23-26).

Several microbial, i.e., exogenous, lipid antigens recognized by iNKT cells have been identified $(27,28), \alpha$-Galactosylceramide ( $\alpha$ GalCer, also referred to as KRN7000), which is derived from the marine sponge Agelas mauritanius, is the most potent member of this group $(29,30)$. Other $\alpha$-anomeric microbial lipids with striking structural similarities to $\alpha$ GalCer and stimulatory effects toward iNKT cells have been found in Sphingomonas spp. $(31,32)$, Borrelia burgdorferi (33), and Streptococcus pneumoniae (34).

By contrast, lipid antigens mediating positive selection and peripheral homeostasis of iNKT cells are obviously of endogenous and not of microbial origin as implicated by the fact that germ-free mice show an unaltered iNKT cell population (35). A variety of endogenous lipids (mostly phospholipids and sphingolipids) have been shown to be captured by CD1d during endosomal-lysosomal recycling or on the secretory pathway (36-39). However, most iNKT cells do not respond to these lipids and the reactivity toward them is restricted to singular iNKT cell clones (40).

Despite an extensive research, the identity of the endogenous lipid antigen(s) responsible for the thymic selection of iNKT cells remains partially unresolved $(41,42)$. It has been demonstrated that mice deficient for glyceronephosphate O-acyltransferase (GNPAT) show an altered iNKT cell development (43). Based on the observation that cells deficient in glucosylceramide (GlcCer)based glycosphingolipids (GSL) (Figure 1) were unable to stimulate iNKT cell hybridomas, it was suggested that the endogenous selecting ligand might be GlcCer or a GlcCer-derived GSL (44). Subsequent studies pinpointed to GlcCer as an endogenous lipid antigen mediating activation of iNKT cells in response to microbial danger signals (45). However, later, the same group reported that a minor-hitherto unidentified-lipid co-purifying with GlcCer might function as the actual self-lipid antigen (46). Until now, in vivo experiments addressing the putative role of GlcCer-derived GSL during thymic iNKT cell development were hampered by an early embryonic lethality of mice deficient for GlcCer synthase (GCS) (47).
In the present study, we have analyzed the GSL composition of double-positive (DP) thymocytes and shown that besides GlcCer, these cells expressed GlcCer-derived acidic GSL from the ganglio series such as GM1a, GM1b, GD1b, and GD1c. Furthermore, we have circumvented the lethality of GCS-deficient embryos by investigating mice with tissue-specific deletion of the GCS gene $\left(\mathrm{Vav}^{\mathrm{Cre}} \mathrm{GCS}^{\mathrm{f} / \mathrm{f}}\right)$ and demonstrated that depletion of GlcCer-derived GSL in DP thymocytes resulted in a significant reduction of the iNKT cell population. Thus, GlcCer-derived GSL represent relevant endogenous lipids contributing to the development of iNKT cells.

\section{MATERIALS AND METHODS}

\section{Experimental Mice}

Mice with floxed GCS (Ugcg, EC 2.4.1.80) alleles were described previously (48). TCRV $\alpha 14-J \alpha 281$ transgenic mice were kindly provided by Agnes Lehuen (49). CDld-deficient (50) and Vav ${ }^{\mathrm{Cr}}$-transgenic (51) mice were purchased from The Jackson Laboratory (Bar Harbor, ME, USA). All strains were backcrossed for more than 10 generations to the C57BL/6 genetic background (Charles River Wiga, Sulzfeld, Germany) and housed under specific pathogen-free conditions. $\mathrm{Vav}^{\mathrm{Cre}}$-negative littermates were used as wild-type (WT) controls. Animal experiments were performed in compliance with the German guidelines on animal protection.

\section{Organ Preparation, Flow Cytometry, and Cell Sorting}

Single cell preparations from organs were prepared as described previously (52). Flow cytometry was performed as described in Ref. (53). The following monoclonal antibodies were used: anti-CD1d (clone: 1B1); anti-CD3e (145-2C11), anti-CD4 (GK1.5), anti-CD8 (53-6.7), anti-CD11c (HL3), anti-CD19 (MB19-1), anti-CD25 (PC61.5), anti-CD44 (IM7), anti-CD150/SLAM (9D1), anti-Ly108 (13G3), antiMHCII (M5/144.15.2), anti-NK1.1 (PK136), anti-TCR-Vß2 (B20.6), anti-TCR-V $\beta 7$ (TR310), and anti-TCR-V $\beta 8.1$ and 8.2 (MR5-2) from BD, Heidelberg, Germany, Biolegend, San Diego, CA, USA, and eBioscience, San Diego, CA, USA. PBS57-loaded PE-labeled CD1d tetramers were kindly provided by NIH Tetramer Core Facility at Emory University (Atlanta, GA, USA). BrdU and Annexin V experiments were performed according to the manufacturer's protocol (both BD). Analysis of flow cytometry data was performed using Cell Quest Pro software (BD) and FlowJo (Tree Star, Flow Cytometry Analysis Software) by gating on lymphocytes in the forward and side scatter. Double-positive thymocytes were sorted using FACSAria ${ }^{\mathrm{TM}}$ (BD) by gating stringently on $\mathrm{CD}^{+} / \mathrm{CD}^{+} \mathrm{DP}$ lymphocytes and excluding $7 \mathrm{AAD}$-positive dead cells.

\section{RNA Isolation and Quantitative PCR}

RNA was extracted from cell pellets using the phenol/chloroform extraction method (54) followed by digestion by RNasefree DNaseI (turbo DNA free, Ambion, Huntingdon, UK). A 


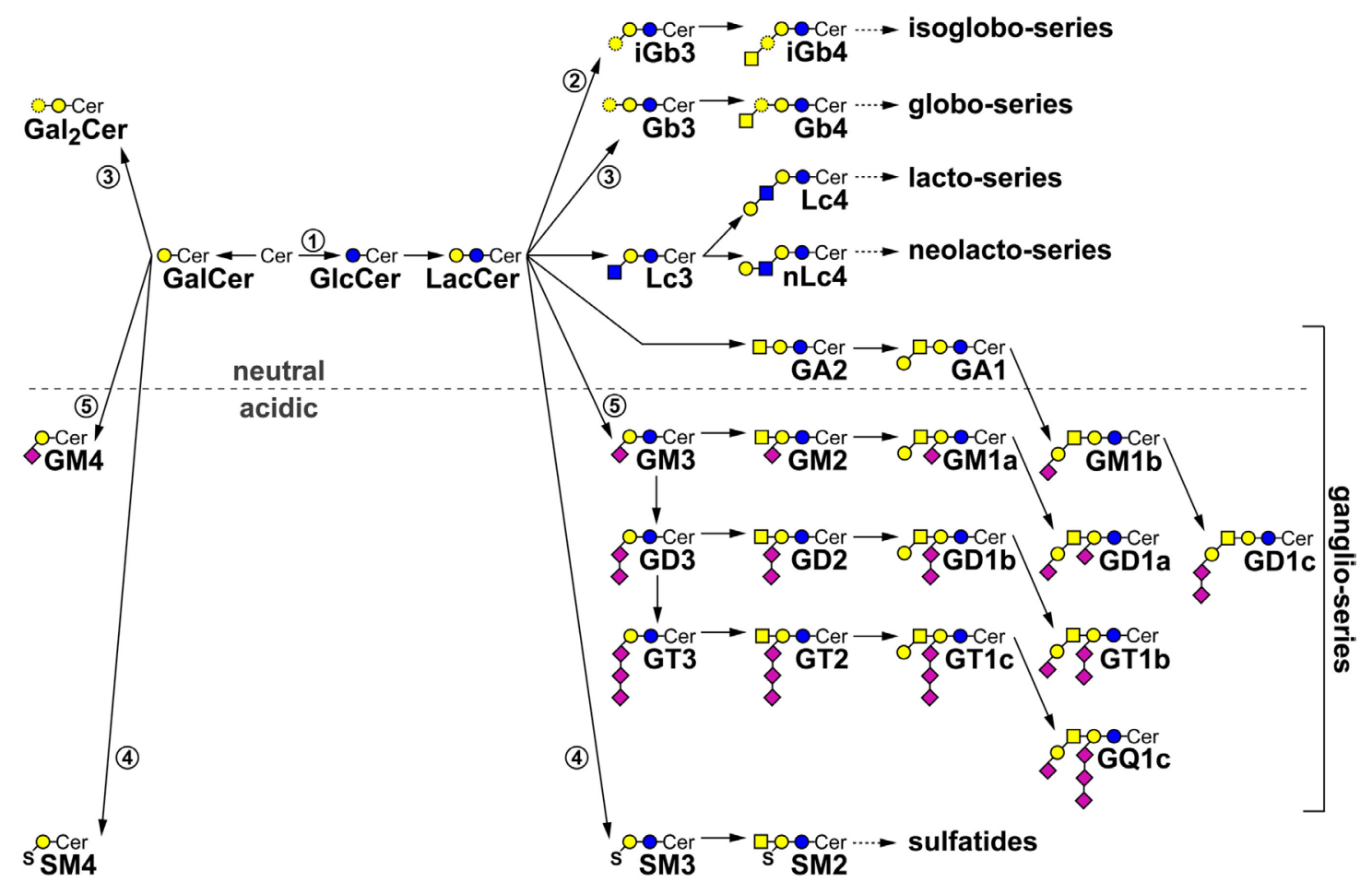

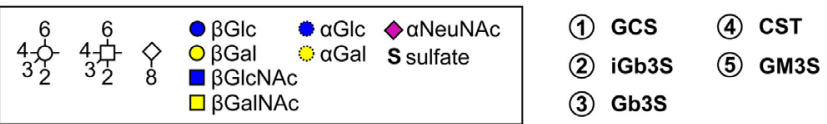

FIGURE 1 | Metabolic glycosphingolipid (GSL) pathways. The diagram shows the most important mammalian metabolic GSL pathways starting from ceramide (Cer) Depending on the first sugar moiety, either galactosylceramide (GalCer) or glucosylceramide (GlcCer) are formed. GlcCer is processed to lactosylceramide (LacCer). By subsequent action of further enzymes on either GalCer or LacCer, individual series of GSL emerge. The presence of an acidic moiety [N-acetylneuraminic acid ( $\alpha$ NeuNAc) in gangliosides or sulfate (S) in sulfatides, respectively] results in an acidic character of these GSL. Relevant synthesis enzymes are indicated as encircled numbers: 1, GlcCer synthase (GCS); 2, isoglobotriaosylceramide (iGb3) synthase (iGb3S); 3, globotriaosylceramide (Gb3) synthase (Gb3S); 4, cerebroside sulfotransferase (CST); and 5, GM3 synthase (GM3S).

total of $3 \mu \mathrm{g}$ of total RNA were reverse transcribed in 20 - $\mu$ l total volume using SuperscriptII (Invitrogen, Karlsruhe, Germany) according to the manufacturers' instructions. RT-PCR was performed with $1 \mu \mathrm{l} \mathrm{cDNA}$ and GCS primers: forward 5' - gat cta aga ggg tga agg cgc a- $3^{\prime}$ and reverse $5^{\prime}-\mathrm{ctg} \operatorname{cct}$ tgc aat cct gtc tgt $\mathrm{c}-3^{\prime}$.

\section{Isolation and Analysis of GSL}

Glycosphingolipids were extracted from lyophilized cell pellets as described in detail in Ref. $(55,56)$. For thin layer chromatography (TLC) analysis, an amount corresponding to $0.2 \mathrm{mg}$ protein was loaded on a TLC plate (Merck, Darmstadt, Germany). Running solvent was $\mathrm{CHCl}_{3} / \mathrm{CH}_{3} \mathrm{OH} / \mathrm{H}_{2} \mathrm{O}(62.5: 30: 6, \mathrm{v} / \mathrm{v} / \mathrm{v})$ for neutral GSL and $\mathrm{CHCl}_{3} / \mathrm{CH}_{3} \mathrm{OH} / 0.2 \% \mathrm{CaCl}_{2}$ in $\mathrm{H}_{2} \mathrm{O}(60: 35: 8$, v/v/v) for acidic GSL, respectively. Sialidase treatment was performed as described in Ref. (57). $0.05 \mathrm{U}$ Vibrio cholerae sialidase in $0.2 \mathrm{M}$ $\mathrm{Na}$-acetate buffer, $2 \mathrm{mM} \mathrm{CaCl}_{2}, \mathrm{pH} 5.2$, was used to digest acidic GSL on a polyisobutylmethacrylate-fixed TLC plate at room temperature for $8 \mathrm{~h}$.

\section{Mass Spectrometric Analyses}

Sphingolipids from DP thymocytes were extracted as previously described with slight modifications (58). Briefly, sorted thymocytes $\left(\sim 5 \times 10^{6}\right)$ were dried with 1-propanol and extracted twice at $37^{\circ} \mathrm{C}$ for $15 \mathrm{~min}$ with a chloroform/methanol/water mixture of $10 / 10 / 1(\mathrm{v} / \mathrm{v} / \mathrm{v})$ and once with $30 / 60 / 8$. The residual cell pellets were used for protein determination according to the Lowry method. The combined lipid extracts were dried under air flow and subsequently subjected to mild alkaline hydrolysis with $0.1 \mathrm{M}$ potassium hydroxide in methanol for $2 \mathrm{~h}$ at $37^{\circ} \mathrm{C}$. Saponified extracts were finally desalted by reverse-phase (C18) column chromatography. Aliquots corresponding to $30 \mu \mathrm{g}$ of protein were dissolved in $1 \mathrm{ml} 95 \%$ methanol containing the following internal standard mixture: Cer (d18:1;14:0), Cer (d18:1;19:0), Cer (d18:1;25:0), Cer (d18:1;31:0) each 4 pmol; GlcCer (d18:1;14:0), GlcCer (d18:1;19:0), GlcCer (d18:1;25:0), and GlcCer (d18:1;31:0) each 2 pmol.

For quantification of lipid extracts, UPLC-ESI-MS/MS analyses were performed as described in Ref. (59) with following 
modifications: lipid extracts were separated in a reverse-phase (C18) column, which was kept at $45^{\circ} \mathrm{C}$, while the autosampler was maintained at $15^{\circ} \mathrm{C}$. After equilibration with buffer A $(95 \%$ methanol, $0.05 \%$ formic acid, and $1 \mathrm{mM}$ ammonium formate), lipids were eluted with increasing percent of buffer B (99\% 2-propanol, $1 \%$ methanol, $0.05 \%$ formic acid, and $1 \mathrm{mM}$ ammonium formate) up to $85 \%$. Ceramide and hexosylceramide species were detected with a precursor ion scan of $m / z+264$ corresponding to sphingosine (d18:1) while keeping the cone voltage at $50 \mathrm{~V}$ and the collision energy at $44 \mathrm{eV}$.

\section{In Vitro and In Vivo Experiments with iNKT and T Cells}

Double-positive thymocytes were isolated from WT, $\mathrm{Vav}^{\mathrm{Cre}} \mathrm{GCS}^{\mathrm{ff} \text {, }}$ and $C D 1 d^{-/-}$thymi after depleting cells reactive with PBS57loaded CD1d tetramers. $0.5 \times 10^{6} \mathrm{DP}$ thymocytes per well were placed in 96-well-plate and incubated with $\alpha$ GalCer (Avanti Polar Lipids, Alabaster, AL, USA) at indicated concentrations. iNKT cells were enriched from livers of TCRV $\alpha 14-J \alpha 281$ transgenic mice using anti-CD5 micro beads (Miltenyi Biotec) and applied at 50,000/well. Activation of T cells in vitro was performed as described in Ref. (60). Briefly, splenic T-cells were enriched by anti-CD90.2 micro beads (Miltenyi Biotec) and incubated with $0.5 \mathrm{mg} / \mathrm{ml}$ calcium ionophore A23187 and $10 \mathrm{ng} / \mathrm{mL}$ phorbol 12-myristate 13-acetate (PMA, both Sigma). Supernatants were collected after $18 \mathrm{~h}$ and analyzed for IFN $\gamma$ and IL 4 concentrations by cytometric bead array technique (BD). For the in vivo testing of iNKT cells function, mice were injected i.p. with 0.2 or $3 \mu \mathrm{g} \alpha \mathrm{GalCer}$ and sacrificed $8 \mathrm{~h}$ later.

\section{Super-Resolution Microscopy}

Thymocytes of WT and $\mathrm{Vav}^{\mathrm{Cre}} \mathrm{GCS} / \mathrm{ff}$ mice were enriched by magnetic separation using CD5 beads (Miltenyi), spinned down using cytospin system $\left(4 \times 10^{5}\right.$ cells/slide $)$ and fixed in $1 \%$ paraformaldehyde in PBS for $15 \mathrm{~min}$ at room temperature. Cells were then incubated with antibodies against CD1d-FITC (BD), early endosome antigen 1 (EEA1) (Cell Signaling), Rab7 (Santa Cruz Biotechnology), and lysosome-associated membrane protein 1 (LAMP1) (eBioscience). After washing, corresponding Alexa-Fluor 546-conjugated secondary antibodies were added and the slides were incubated for $1 \mathrm{~h}$ at room temperature in the dark. DAPI was used for nuclear visualization. Negative controls contained DAPI staining and Alexa-Fluor 546-conjugated secondary antibodies (for EEA1, Rab7, and LAMP1), or DAPI staining only (for CD1d). Images were acquired using the Olympus IX81 motorized microscope equipped with the MT20 illumination system; the Cy3, GFP, and DAPI HC-Filter sets; and Hamamatsu Orca-ER CCD camera. Two hundred images from each channel were acquired for each region using the $100 \times / 1.4$ PlanApo objective, and five regions were analyzed from each sample. Images were post-processed with ImageJ (http:// rsbweb.nih.gov/ij) to obtain super-resolution optical fluctuation images-www.ncbi.nlm.nih.gov/pubmed/20018714. On average, 20 cells were analyzed for co-localization between red and green using the ImageJ's co-localization plugin, and the ratio of co-localized and total green area was plotted and statistically analyzed. The images of lysosomes were further analyzed automatically with the same parameters using ImageJ macro developed at DKFZ Light Microscopy Core Facility (Heidelberg, Germany). Shortly, images of lysosomes were thresholded and segmented using the Find Maxima tool with the Segmented Particles above lower threshold option activated. The segmented particles above the minimum area limit of 10 pixels $\left(0.022 \mu \mathrm{m}^{2}\right)$ were further counted for each cell using ImageJ's Analyze Particles tool.

\section{Statistical Analysis}

Unpaired two-tailed Student's $t$-test was performed to compare data sets. Differences were considered significant if $p<0.05$. Numbers of independent observations per group are indicated for each result.

\section{RESULTS}

\section{GSL Composition of DP Thymocytes}

Because the development of iNKT cells depends on presentation of lipid antigens on DP thymocytes, we analyzed the latter cell population for its GSL composition in WT mice. In the neutral GSL fraction, hexosylceramides represented the major fraction (Figure 2A). In the acidic fraction, two compounds running at the height of GM1 and GD1, respectively, emerged (Figure 2A). In order to further characterize these substances, the acidic fraction was digested by neuraminidase and the products were subsequently separated into acidic and neutral fractions (Figure 2B). The hereby obtained acidic compound ran at the height of the GM1 standard suggesting that this band probably consisted of a mixture of non-digestible GM1 or was derived from GD1b after the release of the terminal sialic acid. By contrast, the neutral compound was not represented in the standards; however, due to its running properties, it likely corresponded to neutral ganglioside GA1 (Figure 2B). To identify this product, the original acidic fraction was on-plate digested with neuraminidase and subsequently immunostained using anti-GA1 antibodies (Figure 2C). Both the upper and the lower compounds had a neutral backbone of GA1 (Figure 2C, left panel). Based on the running properties and the comparison with the standards, these compounds likely correspond to GM1a, GM1b, GD1b, and GD1c.

\section{Characterization of $\operatorname{Vav}^{\mathrm{Cre}} \mathrm{GCS}^{f / f}$ Mice}

Although several lines of evidence have implicated that GlcCerbased GSL might belong to the lipid antigens relevant for the iNKT cell development, a direct proof of this hypothesis was precluded by the early embryonal lethality of GCS-deficient mice (47). To overcome this problem, we implemented a tissue-specific deletion of this gene. To this end, mice with floxed alleles of the GCS gene $\left(G C S^{f / f}\right)$ were crossed with mice expressing iCre under the control of the Vav-promoter ( $\mathrm{VavCre}$ ) that activates the recombinase activity very early in T-cell development with virtually $100 \%$ of $\mathrm{DN} 1\left(\mathrm{CD} 25^{-} / \mathrm{CD} 44^{+}\right)$thymocytes being already positive (51).

In terms of TLC analysis, no GSL could be detected in DP thymocytes from $\mathrm{Vav}^{\mathrm{Cre}} \mathrm{GCS} / \mathrm{f}$ mice (Figure 3A). This was in 


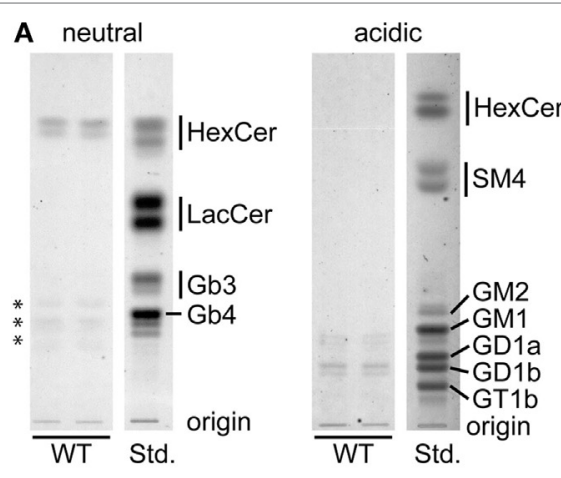

C

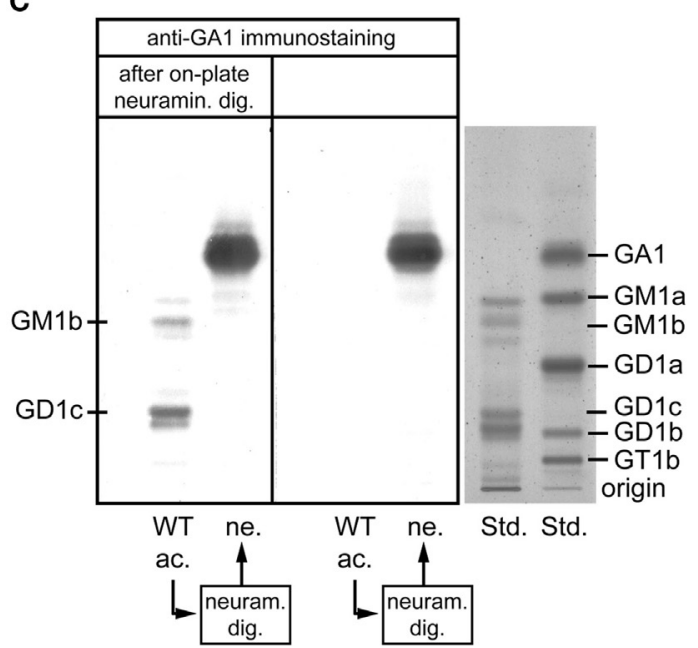

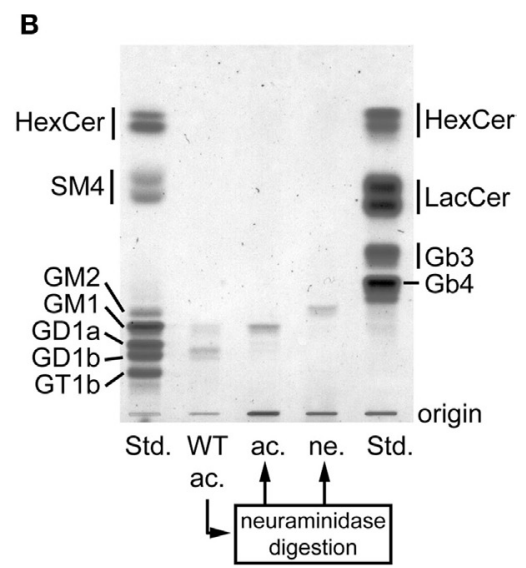
digestion

FIGURE 2 | Glycosphingolipid (GSL) composition of double-positive (DP) thymocytes. (A) Neutral and acidic GSL were extracted from enriched wild-type (WT) DP thymocytes and analyzed by thin layer chromatography (TLC). Some GSL are represented by multiple bands due to their heterogeneous composition of ceramide moieties resulting in different running properties. The substances in the neutral fraction marked by asterisks did not show the typical orcinol color for GSL and therefore very unlikely represent GSL compounds. The displayed lanes represent parts of the chromatograms that are shown and further analyzed in Figure 3A. Orcinol staining. (B) The acidic GSL from WT DP thymocytes were digested by neuraminidase, separated into an acidic (ac.) and a neutral (ne.) fraction and ran in parallel with the original acidic fraction from WT DP thymocytes (WT ac.). The acidic compound obtained after the neuraminidase digestion ran at the height of the GM1 standard. By contrast, the neutral compound was not represented in the standards; however due to its running properties, it corresponded likely to neutral ganglioside GA1. Orcinol staining. (C) To verify from which acidic GSL of WT DP thymocytes its neutral backbone GA1 was released, an immunostaining with anti-GA1 antibodies was performed after additional "on-plate" neuraminidase digestion (left panel). Both the upper and the lower band contained GA1-based compounds. In view of this fact and the running properties, these bands likely correspond to GM1a, GM1b, GD1b, and GD1c. The part of the TLC plate containing GSL standards (Std.) was stained by orcinol.

line with extensive and significant reduction of GCS mRNA in these cells (Figure 3B). Mass spectrometry performed on FACS-sorted DP thymocytes revealed a $99.6 \%$ reduction of the GlcCer content in $\mathrm{Vav}^{\mathrm{Cre}} \mathrm{GCS}^{\mathrm{f} / \mathrm{f}}$ mice as compared to WT (Figure 3C). This reduction occurred independently of the analyzed acyl moiety (Figure 3D). By contrast, the ceramide content of $\mathrm{Vav}^{\mathrm{Cre}} \mathrm{GCS}^{\mathrm{f} / \mathrm{f}} \mathrm{DP}$ thymocytes was indistinguishable from WT (Figures 3E,F).

$\mathrm{Vav}^{\mathrm{Cre}} \mathrm{GCS}^{f / f}$ mice reproduced normally and progeny were born at expected Mendelian ratios (data not shown). Newborn and adult $\mathrm{Vav}^{\mathrm{Cre}} \mathrm{GCS}^{f / f}$ mice did not exhibit any overt growth, developmental or behavioral defects. Body weight, the weight, and cellularity of thymus and spleen were indistinguishable from $\mathrm{Vav}^{\mathrm{Cre}}$-negative littermates (Figure 4A). Similarly, no aberration in the maturation of the conventional thymocytes could be revealed by flow cytometry in $\mathrm{Vav}^{\mathrm{Cre}} G C S^{f / f}$ mice (Figure 4B). In spleens, the amount of CD3- and CD19positive $\mathrm{T}$ - and B-lymphocytes, respectively, was unaffected by the deletion of the GCS gene (Figure 4C). The expression levels of CD1d on $\mathrm{Vav}^{\mathrm{Cre}} \mathrm{GCS} / \mathrm{f}$ DP thymocytes and splenic

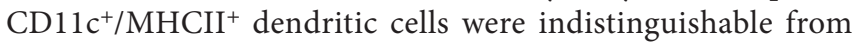
WT mice (Figures 4D,E). The expression of SLAM (CD150) and Ly108 molecules, which provide important signals on DP thymocytes during the thymic iNKT cell development (61), did not significantly differ between $\mathrm{Vav}^{\mathrm{Cre}} G C S^{f / f}$ and WT mice (Figures 4F,G).

Furthermore, CD1d trafficking was analyzed using superresolution microscopy and EEA1, Rab7, and LAMP1 as markers of early endosomes, late endosomes and lysosomes, respectively (Figures 5A-C). The quantification of signal co-localization 
A

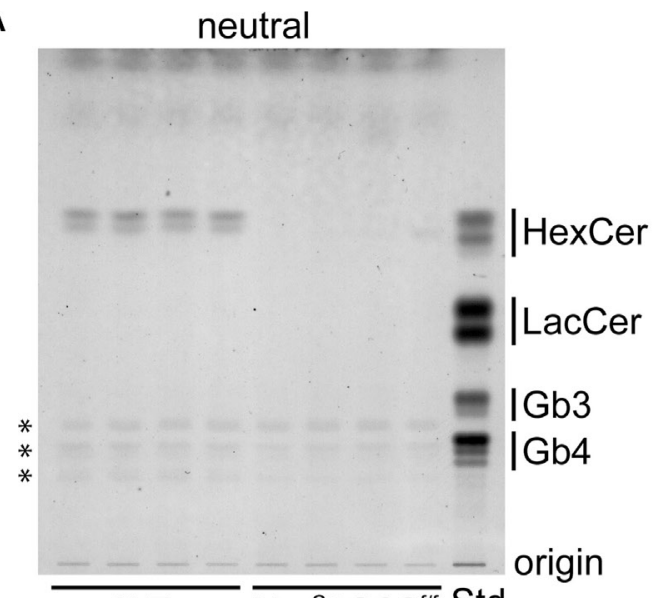

B

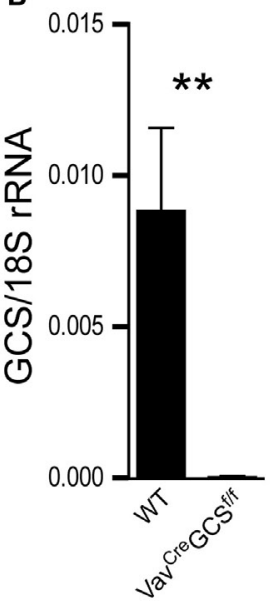

C

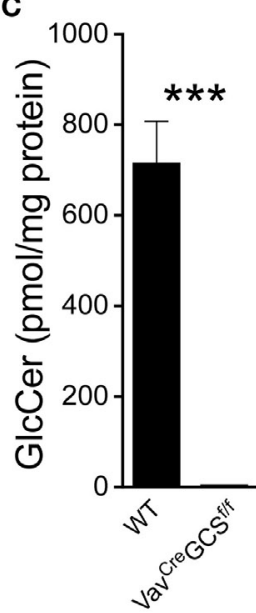

E

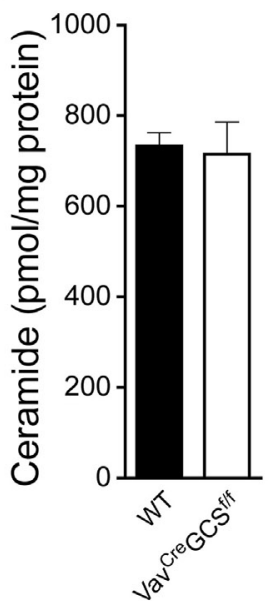

acidic

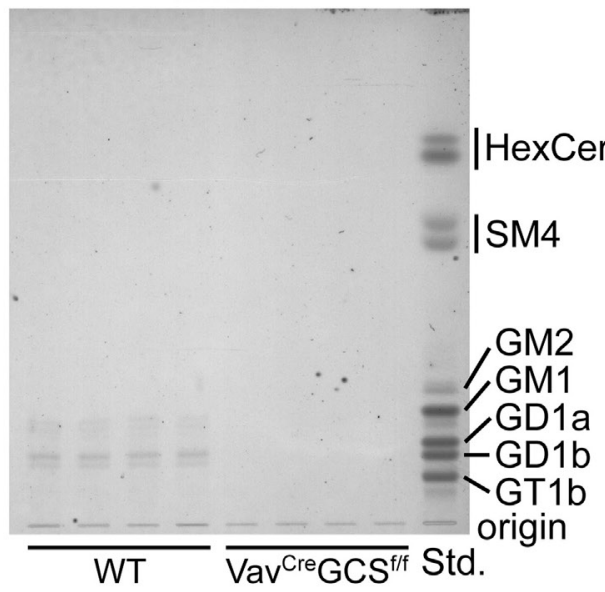

D

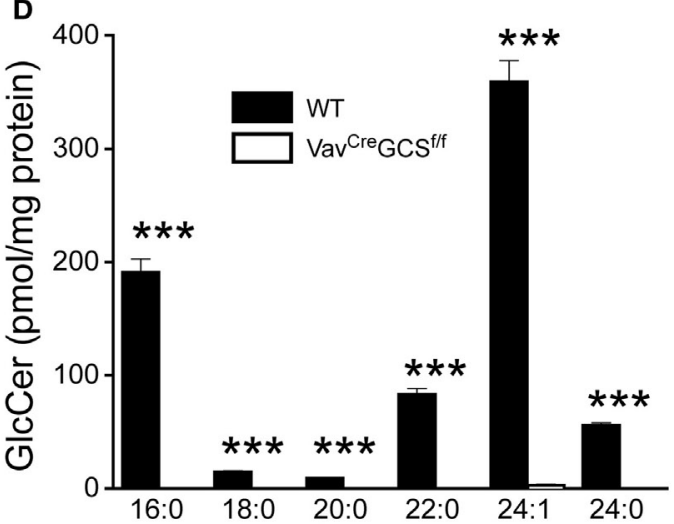

$\mathbf{F}$

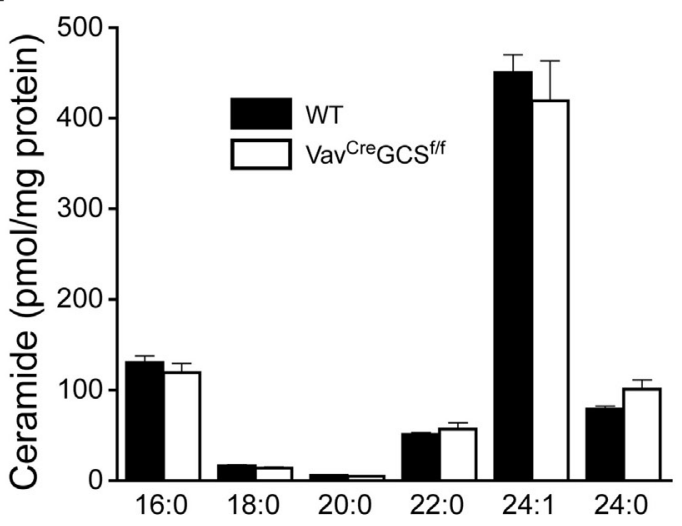

FIGURE 3 | Glycosphingolipid (GSL) depletion in Vav ${ }^{\mathrm{Cre} G C S^{f / f}}$ double-positive (DP) thymocytes. (A) GSL were extracted from enriched DP thymocytes from 8-week-old wild-type (WT) and Vav ${ }^{\text {cre GCS }}$ ff mice, separated into neutral and acidic fractions and analyzed by thin layer chromatography. In DP thymocytes from Vav ${ }^{C r e} G C S^{f / f}$ mice, no residual GSL could be detected. The substances in the neutral fraction marked by asterisks do not show the typical orcinol color for GSL and therefore very unlikely represent those compounds. Shown are results from four different experimental animals per group. (B) FACS-sorted DP thymocytes were analyzed for the expression of GlcCer synthase (GCS) by quantitative PCR. The expression was normalized to $18 \mathrm{~S} r \mathrm{RNA}$. Shown are means \pm SEM, $N=7$ per group. (C-F) GSL were extracted from FACS-sorted DP thymocytes. The content of GlcCer (C,D) and ceramide (E,F) was quantified by mass spectrometry and normalized for the protein amount in the sample. Panels (C,E) show the total amount of GlcCer and ceramide, respectively. In panels (D,F), the composition of acyl moieties of GlcCer and ceramide, respectively, are displayed. Some of the bars for Vav ${ }^{\mathrm{Cre} G C S^{f / f}}$ are barely visible due to very low levels. Shown are means \pm SEM, $N=6$ and 7 per group, respectively. Statistically significant differences between WT and Vav ${ }^{\text {re }}$ GCS ${ }^{f f}$ mice are indicated: ${ }^{* *} p<0.01 ;{ }^{* \star *} p<0.001$. 
revealed a statistically significant shift of CD1d from late to early endosomes in $\mathrm{Vav}^{\mathrm{Cre}} \mathrm{GCS} / \mathrm{f}$ mice. In contrast, the CD1d amount in lysosomes remained unaffected (Figure 5D). Although a tendency toward less but larger lysosomes could be seen in DP thymocytes of $\mathrm{Vav}^{\mathrm{Cre}} \mathrm{GCS} / \mathrm{f}$ mice, the difference was not statistically significant (Figure 5E).
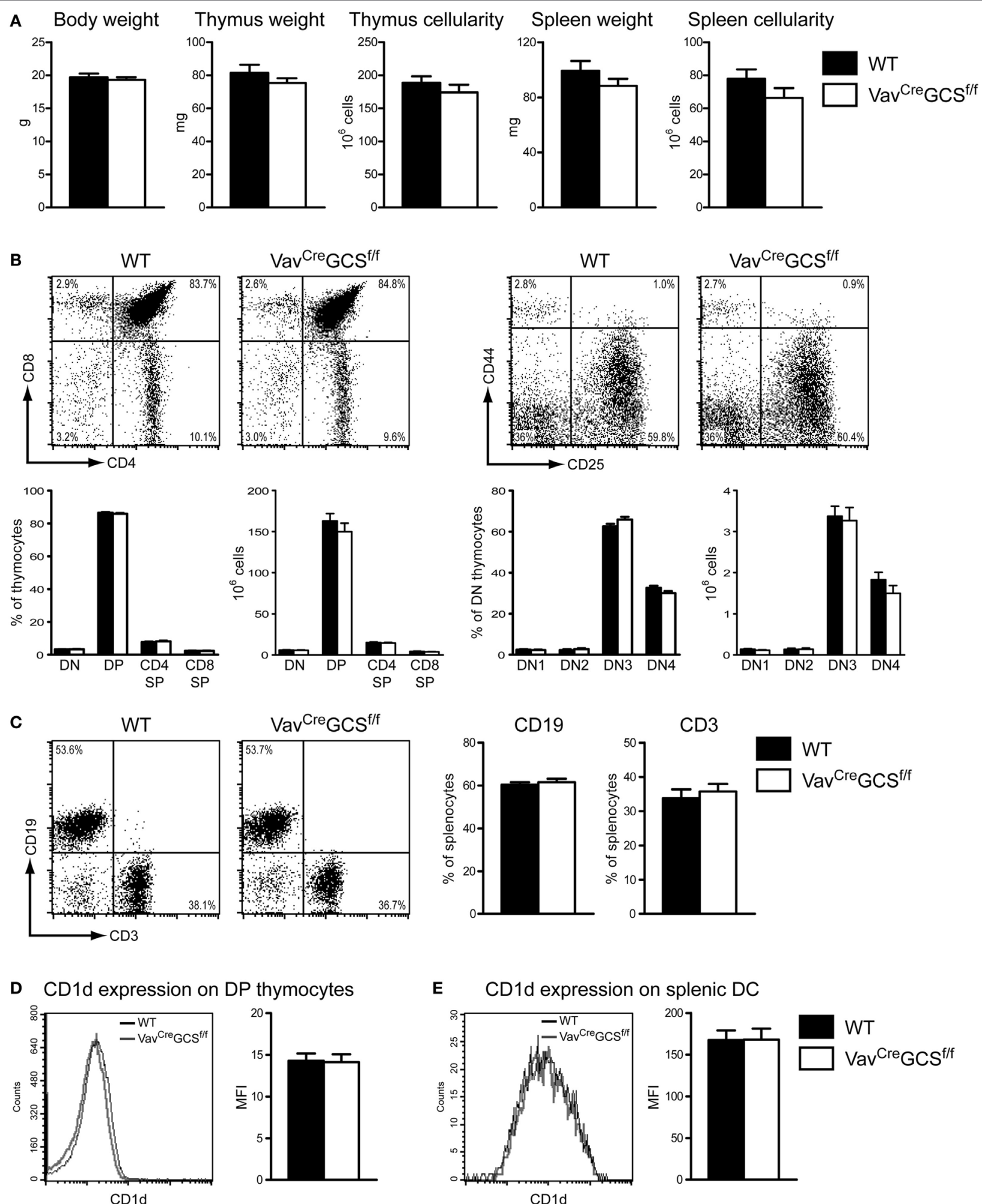

E
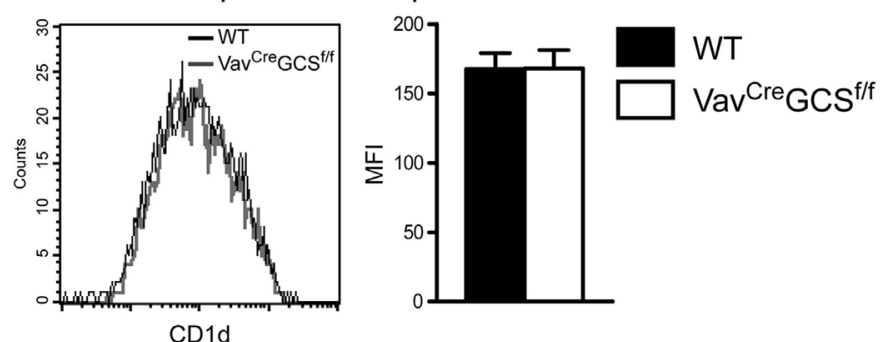

FIGURE 4 | Continued 
$\mathbf{F}$

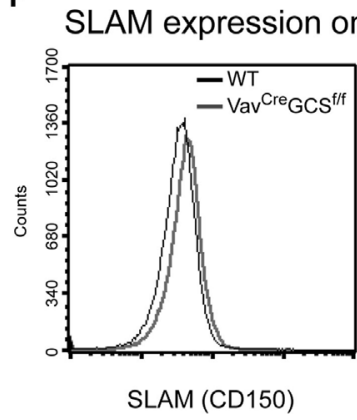

G

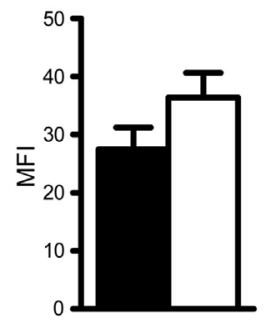

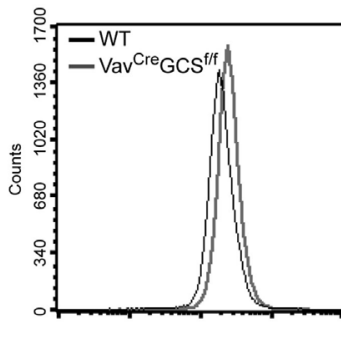

Ly108

FIGURE 4 | Vav ${ }^{\mathrm{Cr} G C S}$ G/f mice showed a typical thymocyte development and an unaltered expression of CD1d, SLAM and Ly108 molecules. (A) No statistically significant differences were observed between 8 week old WT and Vav ${ }^{\text {re }} G C S^{t f}$ mice in terms of body weight and the weight and cellularity of spleen and thymus. Bars show means \pm SEM, $N=6$ per group. (B) Thymocyte development was investigated in 8 week old mice by flow cytometry using antibodies against CD4 and CD8. The double-negative (DN) stage was further subdivided into DN1 (CD25-/CD44+), DN2 (CD25+/CD44+), DN3 (CD25+/CD44-), and DN4 (CD25-/CD44-). Representative dot plots (upper panels) as well as relative and absolute numbers (lower panels) are shown (mean $\pm \mathrm{SEM}, N=13$ per group). No statistically significant differences could be observed between WT and Vav ${ }^{\text {re GCS }}$ fff mice. (C) Frequencies of B (CD3-/CD19+) and T (CD3+/CD19-) cells were measured by flow cytometry in spleens of 8 week old mice. Representative dot-plots and quantifications are shown (mean $\pm S E M, N=13$ per group). No statistically significant differences could be observed between WT and Vav ${ }^{\text {re }} G C S^{f f}$ mice. (D,E) Expression of CD1d was measured on DP (CD4 $4^{+}$CD8 $\left.8^{+}\right)$thymocytes (D) and splenic DC $\left(\mathrm{CD} 11 \mathrm{C}^{+} / \mathrm{MHCll}^{+}\right)$(E) and expressed as mean fluorescence intensity (MFI). No statistically significant difference could be observed between $W T$ and Vav're GCS ${ }^{\prime / f}$ mice. Shown are means \pm SEM, $N=6$ per group in panel (D) and 4 per group in panel (E). (F,G) Expression of SLAM (CD150) and Ly108, respectively, was measured on DP $\left(\mathrm{CD}^{+} / \mathrm{CD}^{+}\right)$thymocytes and expressed as MFI. No statistically significant difference could be observed between WT and Vav ${ }^{\mathrm{Cre}} \mathrm{GCS}{ }^{f / f}$ mice. Shown are means $\pm \mathrm{SEM}, N=4$ per group.

\section{Significant Reduction of the iNKT Cell Population in Vav ${ }^{\mathrm{Cre}} \mathrm{GCS}^{\mathrm{f} / \mathrm{f}}$ Mice}

In newborn and adult mice, the iNKT cell populations were characterized by flow cytometry using PBS57-loaded CD1d tetramers. Adult $\mathrm{Vav}^{\mathrm{Cre}} \mathrm{GCS} \mathrm{S}^{\mathrm{ff}}$ mice showed a significant reduction of the iNKT population in terms of absolute numbers and percentages in thymus, spleen, and liver as compared to WT littermates (Figure 6A). In all three organs, a reduction of the iNKT cell population by approximately $50 \%$ could be observed. In $\mathrm{Vav}^{\mathrm{Cre}} \mathrm{GCS} / \mathrm{f}$ mice, the remaining iNKT cells could be clearly identified and discerned from any unspecific staining as visualized by comparison with CD1d-deficient mice that do not produce iNKT cells (Figure 6A). Newborn mice showed identical results (data not shown). To test for possible unspecific effects of the $\mathrm{Vav}^{\text {Cre }}$ transgene, iNKT cell frequencies and absolute numbers were compared between $\mathrm{Vav}^{\mathrm{Cre}}$-positive and $\mathrm{Vav}^{\mathrm{Cre}}$-negative $\mathrm{GCS}^{+/+}$mice showing no statistically significant differences (Table S1 in Supplementary Material).

In course of thymic maturation, iNKT cells upregulate expression of NK1.1 and CD44 allowing the identification of three developmental stages: immature, $\mathrm{CD} 44^{-} / \mathrm{NK} 1.1^{-}$; semi-mature, $\mathrm{CD} 44^{+} / \mathrm{NK} 1.1^{-}$; and mature, $\mathrm{CD} 44^{+} / \mathrm{NK} 1.1^{+}(62)$. In terms of absolute numbers, iNKT cells were significantly reduced in all three developmental stages in $\operatorname{Vav}^{\mathrm{Cre}} G C S^{f f}$ mice. However, no significant difference was observed in the percentual distribution among these three stages (Figure 6B).

In iNKT cells, the invariant V $\alpha 14$-chain pairs almost exclusively with V $\beta 2,7$, or 8.2 (63). We tested whether the depletion of GCS-derived GSL would lead to a shift of the V $\beta$-chain repertoire in $\mathrm{Vav}^{\mathrm{Cre}} \mathrm{GCS} / \mathrm{ff}$ mice. However, no statistically significant difference in the percentage distribution of the $\mathrm{V} \beta$-chains could be found between $\mathrm{Vav}^{\mathrm{Cre}} \mathrm{GCS} / \mathrm{f}$ mice and WT littermates. In terms of absolute numbers, a decrease corresponding to the diminished iNKT cell population could be observed (Figure 6C).

Measurements of proliferation and apoptosis rate by BrdU incorporation and Annexin $\mathrm{V}$ staining, respectively, revealed that in $\mathrm{Vav}^{\mathrm{Cre}} \mathrm{GCS} / \mathrm{ff}$ mice, thymic iNKT cells showed a significantly reduced proliferation and an increased apoptosis as compared to WT mice. By contrast, conventional thymocytes were unaffected (Figures 6D,E).

\section{Deletion of GCS Did Not Affect the Processes of Antigen Presentation and Recognition}

Depletion of GCS-derived GSL in DP thymocytes might not only alter the repertoire of lipid antigens but also impact the processes of their presentation. Thus, in order to test the antigen presenting capacity of $\mathrm{Vav}^{\mathrm{Cre}} G C S^{f / f}$ DP thymocytes, these cells were exposed to increasing concentrations of the exogenous antigen $\alpha \mathrm{GalCer}$ and co-incubated with WT responder iNKT cells enriched from livers of TCRV $\alpha 14-\mathrm{J} \alpha 281$ transgenic mice. As measured by secretion of IFN $\gamma$ and IL4, no statistically significant difference could be observed between the antigen presentation on DP thymocytes from $\mathrm{Vav}^{\mathrm{Cre}} \mathrm{GCS} / \mathrm{ff}$ and WT mice (Figures 7A,B).

Furthermore, we have subjected $V a v^{C r e} G C S^{f / f}$ iNKT cells to functional tests in vivo and in vitro. Upon injection of $\alpha$ GalCer, upregulation of CD69 on iNKT cells was unaltered in $\mathrm{Vav}^{\mathrm{Cre}} \mathrm{GCS} / f$ mice (Figure 7C). IFN $\gamma$ levels were significantly lower in $\mathrm{Vav}^{\mathrm{Cre}} \mathrm{GCS}^{f / f}$ mice injected with $3 \mu \mathrm{g} \alpha \mathrm{GalCer}$. Similarly, IL4 levels tended to be lower in the $\mathrm{Vav}^{\mathrm{Cre}} \mathrm{GCS} / \mathrm{f}$ mice although a statistical significance was not reached (Figure 7C). Therefore, we tested the reactivity of $\mathrm{Vav}^{\mathrm{Cre}} \mathrm{GCS} / \mathrm{f}$ iNKT cells in vitro with equalized cell numbers. To this end, WT DP thymocytes 

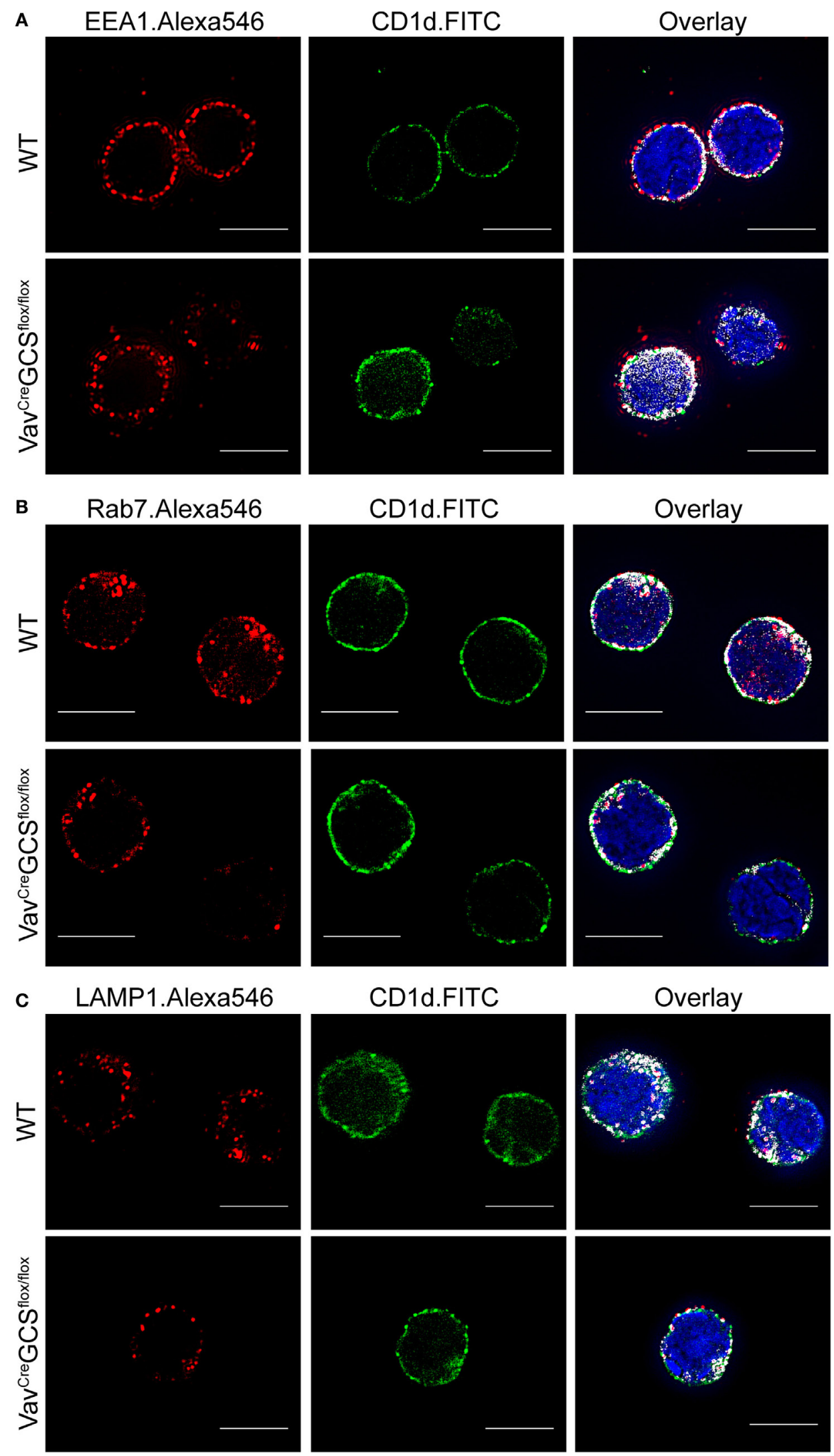

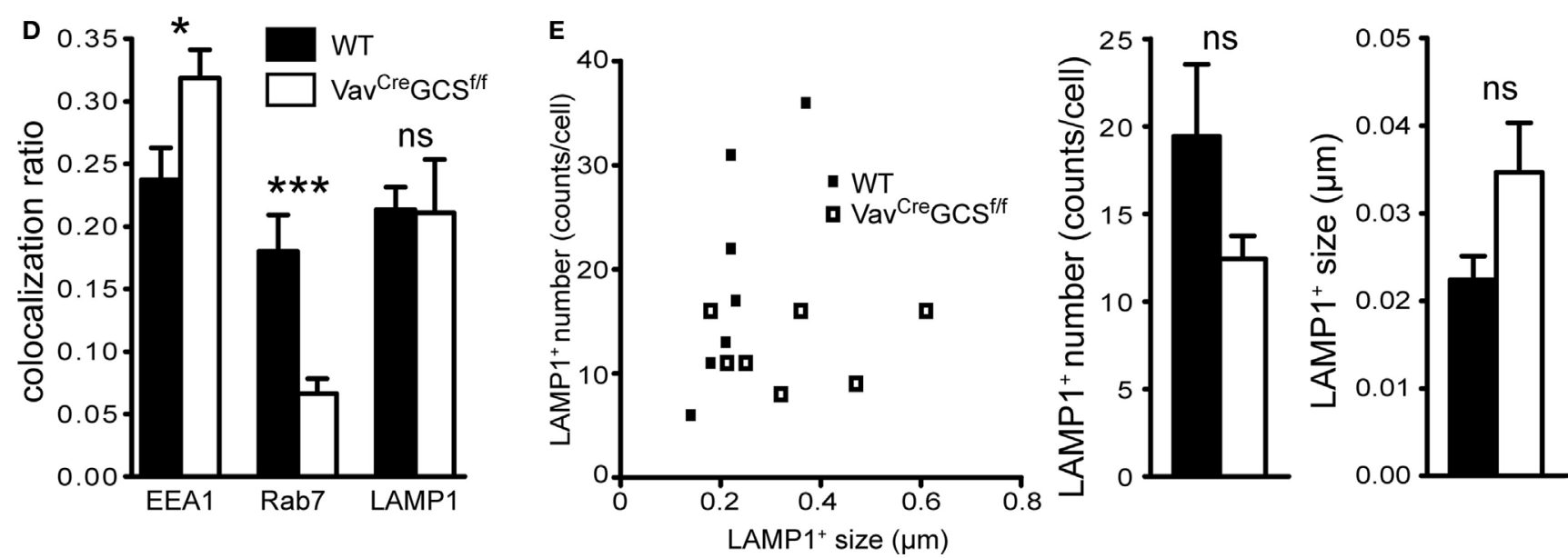

FIGURE 5 | CD1d trafficking through early endosomes, late endosomes, and lysosomes. (A-C) In double-positive (DP) thymocytes, super-resolution microscopy was used to determine intracellular localization of CD1d molecules in early endosomes, late endosomes, and lysosomes visualized in the red channel by early endosome antigen 1 (EEA1), Rab7, and lysosome-associated membrane protein 1 (LAMP1), respectively. Co-localization areas were presented in white (right panels). DAPI was applied to visualize the nucleus (bar $=5 \mu \mathrm{m})$. (D) DP thymocytes were analyzed for co-localization between green and red signals using the ImageJ's co-localization plugin, and the ratio of co-localized and total green area was plotted and statistically analyzed using the unpaired t-test. Although a significant shift from late to toward early endosomes could be observed in Vav ${ }^{\text {Cre GCS }}{ }^{f / f}$ DP thymocytes, the amount of CD1d in lysosomes was equal. Shown are means \pm SEM, $N=20$ cells per group. (E) A tendency toward less but larger LAMP1+ lysosomes could be seen in DP thymocytes of Vav Cre GCS ${ }^{t / f}$ mice, however, the difference was not statistically significant. The bars show means $\pm \mathrm{SEM}, N=7$ cells per group.

were loaded with $\alpha$ GalCer and co-incubated with iNKT cells enriched from spleens and livers of $\mathrm{Vav}^{\mathrm{Cre}} \mathrm{GCS} / \mathrm{f}$ or WT mice. No functional deficiency could be observed between iNKT cells from $\mathrm{Vav}^{\mathrm{Cre}} \mathrm{GCS} / \mathrm{f}$ and WT mice as measured by IFN $\gamma$ secretion (Figure 7D).

In line with the latter result, the general $\mathrm{T}$ cell population of $\mathrm{Vav}^{\mathrm{Cre}} \mathrm{GCS} / \mathrm{ff}$ mice was unaffected and showed an unaltered production of IFN $\gamma$ in response to TCR-independent (PMA/ calcium ionophore) or TCR-dependent (CD3/CD28) stimulation (Figure 7E).

\section{DISCUSSION}

Although substantial progress in understanding the function of iNKT cells has been achieved since their discovery two decades ago, the identity of the endogenous lipid antigen(s) mediating their thymic positive selection and peripheral activation remains largely elusive. Originally, it has been shown that cells deficient in GlcCer-based GSL were unable to stimulate iNKT cell hybridomas, thus implicating that the endogenous ligand might be GlcCer or a GlcCer-derived GSL (Figure 1) (44). However, mice deficient for singular series of GlcCer-derived GSL such as gangliosides, globosides, isoglobosides, and sulfatides were shown to have normal iNKT cell numbers; thus, casting doubts upon a decisive role of GlcCer-derived GSL in the positive selection of iNKT cells $[(53,56)$ and own unpublished results]. Similarly, $\beta$ GalCer-derived GSL were demonstrated to be dispensable for iNKT cell development (44). Interestingly, mice deficient in several GSL-degrading enzymes ( $\alpha$-galactosidase A, $\beta$-galactosidase, $\beta$-hexosaminidase A/B, Niemann-Pick-disease type C1-protein) have significantly reduced iNKT cell numbers (64). In case of $\alpha$-galactosidase A-deficient mice, which store globosides and isoglobosides, Darmoise et al. attributed the diminished iNKT cell population to excessive levels of the isogloboside iGb3 that would elicit apoptosis of iNKT cells by continuous overstimulation (65). However, using a genetic approach, we could show that in $\alpha$-galactosidase A-deficient mice, the reduction of iNKT cells was a consequence of lysosomal dysfunction and not of iGb3 per se (56).

The paradox that iNKT cell development remains unaltered after depletion of singular GlcCer-derived GSL groups offers three explanations: (a) lipids other than GSL, (b) other-yet unaddressed-GlcCer-derived GSL, or (c) the GlcCer itself mediate the positive selection of iNKT cells. Several lines of evidence have shown that also lipids other than GSL might be important for the iNKT cell activation and development $(38,43)$. The first publication has demonstrated that etherbonded mono-alkyl glycerophosphates stimulated iNKT cells and that deficiency for GNPAT led to an approximately 50\% reduction of the iNKT cell population in vivo (43). However, GNPAT-deficient mice have multiple severe abnormalities and those that survive develop hypomorphism (66), altogether making the exclusion of any unspecific effects on the iNKT cell population very challenging. By contrast, Brennan et al. have pinpointed to $\beta$ GlcCer as the self-antigen responsible for activation of iNKT cells by dendritic cells upon recognition of microbial danger signals (45). However, their later findings implicated that not $\beta$ GlcCer but a rare, yet unknown, component of the GlcCer fraction should be responsible for the stimulation of iNKT cells (46). Recently, Kain et al. could identify trace amounts of $\alpha$-anomeric GSL in mammalian immune cells and demonstrate their stimulatory capacity toward iNKT cells (67). Independently of these ambiguous results on GlcCer with regard to its stimulatory role for iNKT cells in the periphery, it remained 
unknown whether GlcCer-derived GSL (be it $\alpha$ - or $\beta$-anomers) might represent also the endogenous lipid antigen in the process of thymic iNKT cell selection.
We describe here the first functional in vivo model that has allowed for a depletion of GlcCer and GlcCer-derived GSL in DP thymocytes and that has shown a significant reduction

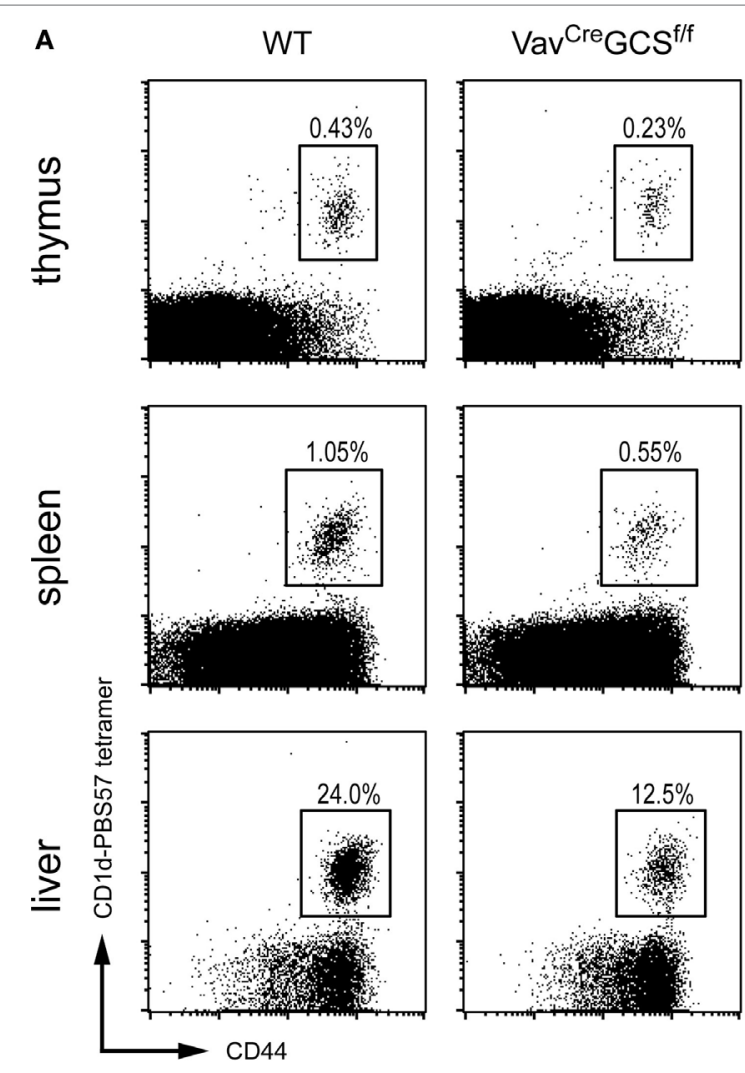

B

Thymic development of iNKT cells
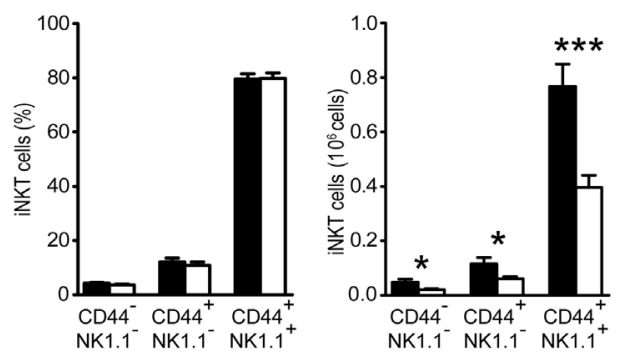
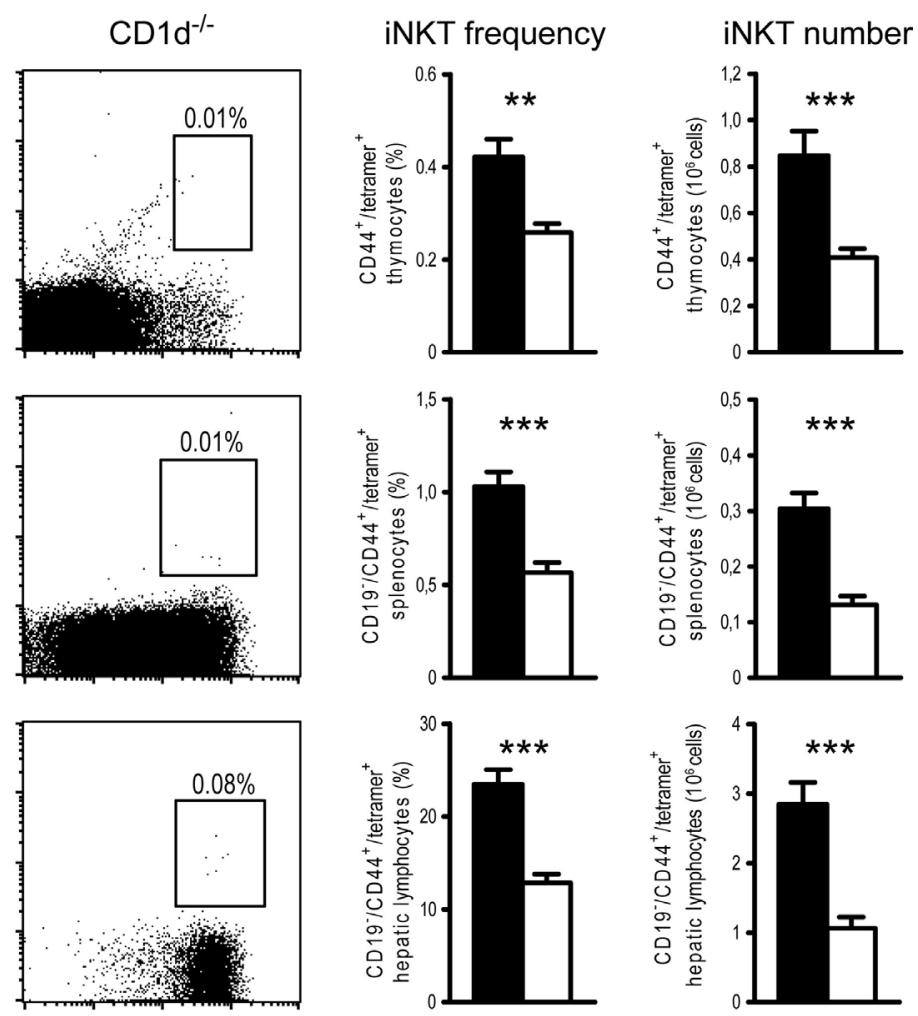

C

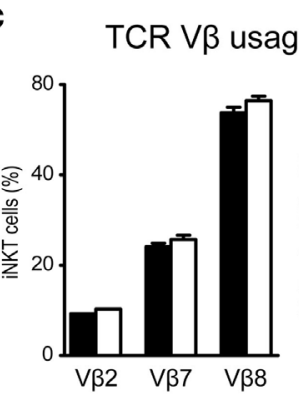

ge of iNKT cells

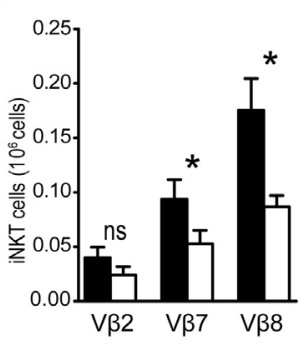

D

Proliferation

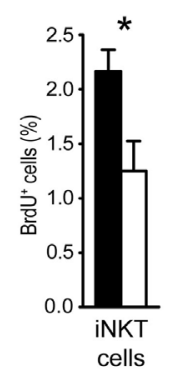

E

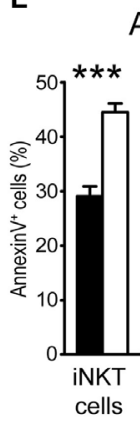

Apoptosis

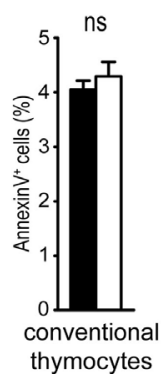

WT

$\square \operatorname{Vav}^{\mathrm{Cre}} \mathrm{GCS}^{\mathrm{f} / \mathrm{f}}$ 


\begin{abstract}
FIGURE 6 | Continued

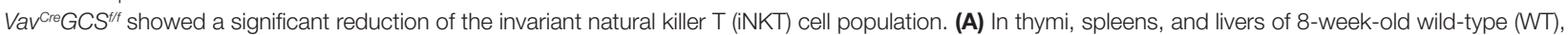
Vav $^{\text {Cre GCS }}$ fff $^{t / 4} C D 1 d^{-1-}$ mice, frequencies and absolute numbers of iNKT cells were measured by flow cytometry using PBS57-loaded CD1d tetramers and anti-CD44 antibodies. In spleens and livers, CD19+ cells were gated out. In Vav ${ }^{\text {Cre GCS }}{ }^{f / f}$ mice, iNKT cells frequencies and numbers were significantly reduced in all

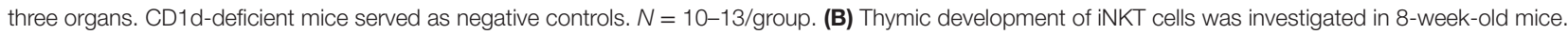
Antibodies against NK1.1 and CD44 were used to subdivide the developmental stages in immature (CD44-/NK1.1-), semi-mature (CD44+/NK1.1-), and mature $\left(\mathrm{CD} 44^{+} / \mathrm{NK} 1.1^{+}\right)$. Analyses were gated on iNKT cells defined as CD3+/PBS57-CD1 ${ }^{+}$thymocytes. Shown are relative and absolute numbers (left and right panels, respectively) of iNKT cells with the corresponding phenotype. No statistically significant differences could be observed between WT and Vav're GCS f $/ f^{\prime}$ mice in terms of relative numbers (i.e., distribution among the three stages). The significant reduction in absolute numbers reflected the overall diminished iNKT cell population in Vav ${ }^{\text {Cre GCS }}{ }^{\text {f/f }}$ mice. $N=16$ /group in the left panel and 10/group in the right panel, respectively. (C) Usage of TCRV $\beta$-chains by splenic iNKT cells was investigated in 8-week-old mice. Analyses were gated on CD19-/PBS57-CD1d+/CD44+ splenocytes. Shown are relative and absolute numbers (left and right panels, respectively) of iNKT cells expressing the corresponding TCRV $\beta$-chain. No statistically significant differences could be observed between WT and VavCre GCS ${ }^{t / f}$ mice in terms of relative numbers (i.e., distribution among the three TCRV $\beta$-chains). The reduction in the absolute numbers reflected the diminished iNKT cell population in Vav ${ }^{\text {Cre GCS }}{ }^{\text {f/f }}$ mice. $N=9$ /group in the left panel and 6/group in the right panel, respectively. (D,E) Proliferation and apoptosis of thymic iNKT cells were measured in 8-week-old mice using BrdU incorporation and Annexin $V$ staining, respectively. In Vav ${ }^{\text {Cre GCS }}{ }^{f / f}$ mice, iNKT cells (CD3+/PBS57-CD1d ${ }^{+}$thymocytes) showed a significantly reduced proliferation and an increased apoptosis as compared to WT controls. By contrast, conventional thymocytes were unaffected. $N=5 /$ group. Bars represent means \pm SEM; ${ }^{*} p<0.05 ;{ }^{* \star} p<0.01 ;{ }^{* \star *} p<0.001 ;$ ns, non-significant.
\end{abstract}

in iNKT cells. Due to the very early activation of the Vav-cre promoter in hematopoietic progenitors (51), it was possible to achieve not only a deletion of the GCS mRNA but also a highly efficient depletion of its product GlcCer that averaged at $99.6 \%$ in DP thymocytes. The finding of the residual $0.4 \%$ GlcCer in $\operatorname{Vav}^{\mathrm{Cre}} G C S^{f / f} \mathrm{DP}$ thymocytes might have several explanations: (a) it represents residual, not yet catabolized, traces of intrinsic GlcCer in $\operatorname{Vav}^{\mathrm{Cre}} G C S^{f / f}$ DP thymocytes. (b) Thymocytes could potentially utilize blood-derived GSL in vivo as it has been shown also for other cell types (68). Of note, we have omitted any exposure of the thymocytes to fetal calf serum or albumin during their ex vivo preparation and sorting. (c) Contamination by epithelial cells or cell fragments before or during the sorting might have artificially contributed to the measured residual GlcCer levels. For conventional $\mathrm{T}$ cells, it has been demonstrated that even a single antigen-MHC complex can elicit their activation $(69,70)$. Therefore, it cannot be excluded that also such trace amounts of GlcCer still found on DP thymocytes would enable sufficient activation of iNKT cells and thus be-at least partially-responsible for the remaining approximately $50 \%$ of iNKT cells in $\mathrm{Vav}^{\mathrm{Cre}} \mathrm{GCS}^{\mathrm{f} / \mathrm{f}}$ mice. Alternatively, the coexistence of multiple endogenous antigens might explain the incomplete reduction of iNKT cells upon $99.6 \%$ reduction of GlcCer. The aforementioned work by Facciotti et al. describing also an approximately 50\% reduction of iNKT cells in GNPAT-deficient mice might indeed support such an assumption and speak in favor of a coexistence of GlcCer and GNPAT-derived ligands. In addition, it has been demonstrated that iNKT cells recognize also other self-lipids that can be loaded on CD1 molecules (e.g., phosphatidylinositol, phosphatidylethanolamine, lysophospholipids, sphingolipids) $(36-39,71,72)$. The in vivo role of these lipids and their possibly interchangeable function will have to be addressed by further studies.

In view of the potential ligand heterogeneity, it might be speculated that the depletion of one ligand might alter the CD1d-TCR interaction and indirectly influence the V $\beta$ repertoire. However, the TCR V $\beta$ repertoire remained unchanged in $\mathrm{Vav}^{\mathrm{Cre}} \mathrm{GCS} / \mathrm{f}$ mice. In iNKT cells, the interaction between CD1dbound antigen and the TCR is mediated mainly by the TCR $\alpha$-chain that is also in contact with the antigen. The $\beta$-chain, as contrasted to the conventional T cells, contacts the CD1d molecule only marginally with a minimal, if any, access to the lipid antigen $(17,18)$. This might offer an explanation of the fact that the antigen depletion did not elicit any alteration of the TCRV $\beta$ repertoire in $\mathrm{Vav}^{\mathrm{Cre}} \mathrm{GCS}^{f / f}$ mice.

The finding of unaltered conventional T cells in $\mathrm{Vav}^{\mathrm{Cre}} \mathrm{GCS}^{f / f}$ mice is surprising because GSL contribute to the formation of membrane microdomains that are important for the signal transduction. However, our results indicate that GlcCer-derived GSL are dispensable for the conventional $\mathrm{T}$ cell population as their thymic development, peripheral frequency and response to TCR-dependent and -independent stimulation were unaffected in $\mathrm{Vav}^{\mathrm{Cre}} G C S^{\mathrm{f} / \mathrm{f}}$ mice. In line with this, in vitro and in vivo activation of iNKT cells by the exogenous antigen $\alpha$ GalCer was unaffected in $\mathrm{Vav}^{\mathrm{Cre}} \mathrm{GCS} / \mathrm{f}$ mice. Thus, it seems unlikely that the reduction of iNKT cells would be a consequence of an unspecific or cell-intrinsic T cell phenotype.

The presented results also have shown that expression of SLAM, Ly108, and CD1d on DP thymocytes does not depend on GlcCer and GlcCer-derived GSL. The described shift of CD1d from late to early endosomes remains as yet unexplained. However, the normal expression of CD1d in lysosomes and on the cell surface together with the unaltered antigen presentation on $\mathrm{Vav}^{\mathrm{Cre}} G C S^{f / f}$ DP thymocytes make a functional impact of GlcCer-derived GSL on the processes of antigen presentation unlikely. This corresponds to previous in vitro observations that CD1d expression levels and presentation of exogenous synthetic antigens were unaffected in GSL-deficient cells (38). In view of the unaltered CD1d functionality and normal expression of SLAM and Ly108 on DP thymocytes, the reduced proliferation and increased apoptosis of $\mathrm{Vav}^{\mathrm{Cre}} \mathrm{GCS} \mathrm{S}^{\mathrm{f} / \mathrm{f}}$ iNKT cells (but not conventional thymocytes) speaks in favor of a diminished presentation of an endogenous antigen on DP thymocytes.

We have analyzed the GSL spectra of WT DP thymocytes and found that they expressed a hexosylceramide compound that was absent in thymocytes deficient for GCS, thus implicating that it was GlcCer and not GalCer. In addition, DP thymocytes expressed also gangliosides such as GM1a, GM1b, GD1b, and GD1c. These results agree with a recent report analyzing the 

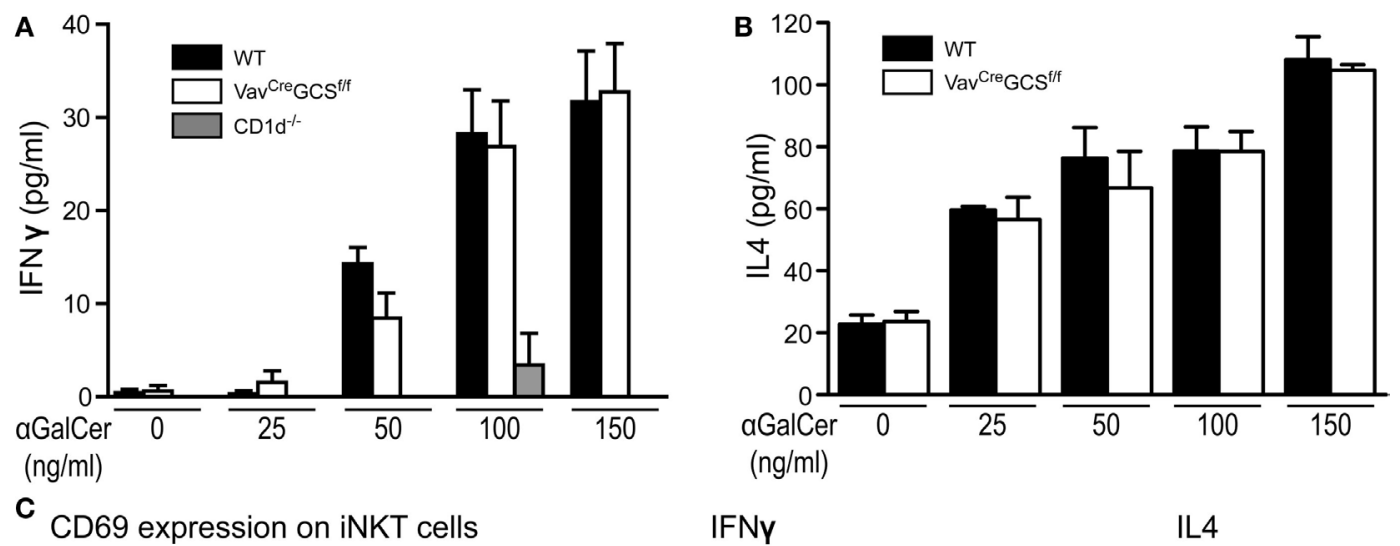

CD69 expression on iNKT cells

IFNY

IL4
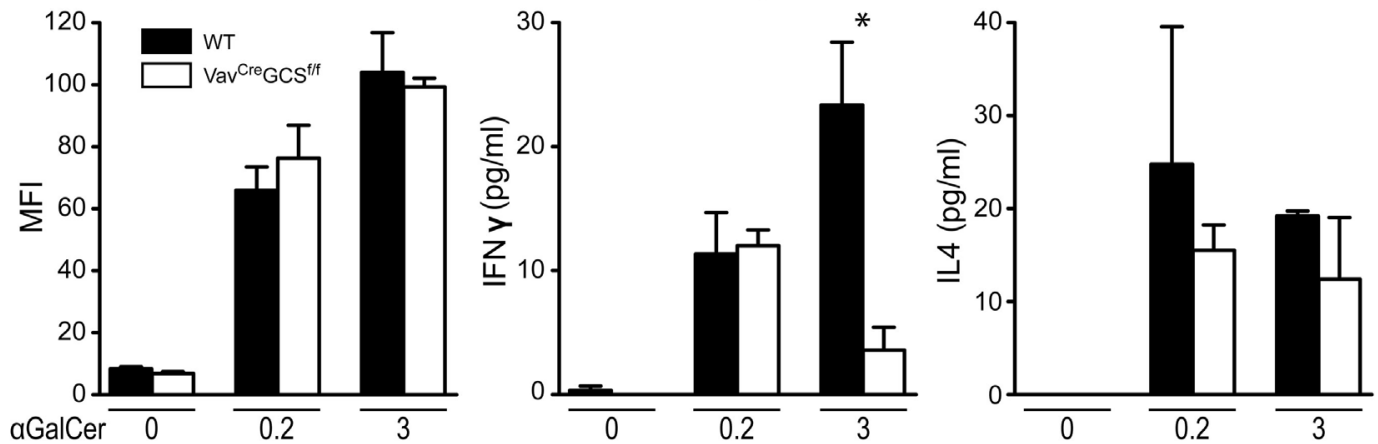

$(\mu \mathrm{g})$
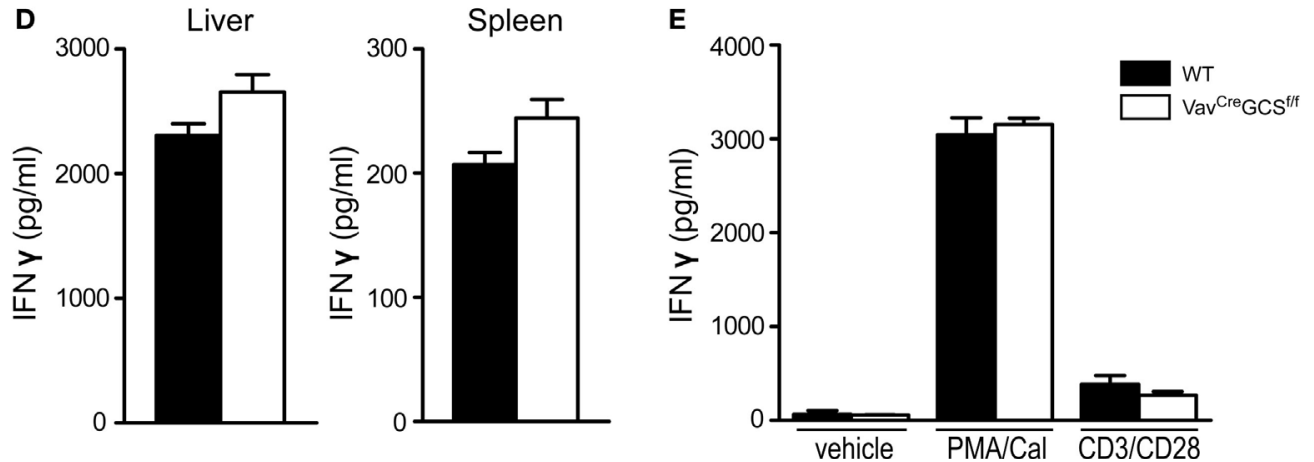

FIGURE $7 \mid$ Antigen presentation and recognition in Vav ${ }^{\mathrm{Cre}} \mathrm{GCS}^{\prime / f}$ mice. (A,B) Double-positive (DP) thymocytes were tested for their antigen presentation capacity toward invariant natural killer T (iNKT) cells in vitro. To this end, iNKT-depleted wild-type (WT), Vav ${ }^{\text {Cre GCS }}$ fff $^{f f}$, and CD1 $d^{-1-}$ DP thymocytes were exposed to increasing concentrations of $\alpha \mathrm{GalCer}$ and co-incubated with responder WT iNKT cells enriched from livers of TCRV $\alpha 14-J \alpha 281$ transgenic mice. The activation measured as secretion of IFN $\gamma$ (A) and IL4 (B) did not differ between WT and Vav ${ }^{\text {Cre GCS }}$ (tf $^{\text {DP }}$ thymocytes. CD1 $d^{-1-D P}$ thymocytes served as negative controls, and the corresponding bars cannot be discriminated from the zero line in all but one concentration. Shown are means \pm SEM, $N=6-9$ per group. (C) Activation of iNKT cells was tested in vivo. WT and Vav ${ }^{\text {Cre GCS }}{ }^{\prime f}$ mice were i.p. injected with either 0.2 or $3 \mu g \alpha G a l C e r$. Eight hours later, splenic iNKT cells were analyzed for surface CD69 expression by flow cytometry by gating on CD19-/PBS57-CD1d+/CD44+ lymphocytes. Expression of CD69 did not

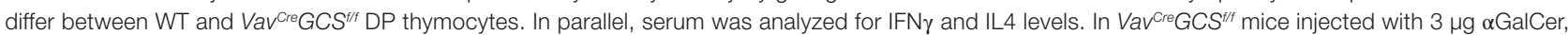
IFN $\gamma$ levels were significantly lower than in the WT controls. All other measurements did not show a statistically significant difference. Shown are means \pm SEM, $N=3$ per group. (D) Activation of iNKT cells was tested in vitro. iNKT cells from livers and spleens of WT and Vav Cre GCS ${ }^{t / f}$ mice were exposed to $\alpha$ GalCer-loaded WT DP thymocytes. The activation measured as IFN $\gamma$ secretion did not differ between WT and Vav ${ }^{\text {Cre GCS }}$ f/f iNKT cells. Shown are means \pm SEM, $n=3-6$ per group. (E) Splenic conventional T cells were tested for their T cell receptor (TCR)-independent and TCR-dependent activation in vitro. WT and Vav ${ }^{\mathrm{rre}} \mathrm{GCS}$ f/f splenic T cells were activated by PMA/calcium ionophore A23187 or by plate-bound anti-CD3/anti-CD28 antibodies. Vehicle (media)-treated cells served as controls. No statistically significant differences could be found in the IFN $\gamma$ secretion between WT and Vav ${ }^{\text {cre GCS }}{ }^{\text {fff }} \mathrm{T}$ cells. Shown are means \pm SEM, $n=6$ per group.

GSL composition of unsorted thymocytes and CD4- and CD8positive T cells (73). However, gangliosides unlikely represent the iNKT selecting endogenous ligands as mice deficient for ganglioside-synthesizing enzymes were shown to have normal iNKT cell populations $(56,74)$. These findings pinpoint to GlcCer (and not its downstream metabolites gangliosides) as a 
GSL present on DP thymocytes and of importance in iNKT cell selection.

In summary, our results demonstrate in vivo that GCSdependent GSL, in particular GlcCer, influence the homeostatic iNKT cell development.

\section{ETHICS STATEMENT}

Animal experiments were performed in compliance with the German guidelines on animal protection and approved by the committee (Regierungspräsidium Karlsruhe).

\section{AUTHOR CONTRIBUTIONS}

SP initiated the study and wrote the manuscript. ZP, MR, RJ, DK, RS, and SP performed and evaluated experiments. H-JG provided animals, reagents, and technical assistance and gave critical input to the study and to the manuscript.

\section{REFERENCES}

1. Chandra S, Kronenberg M. Activation and function of iNKT and MAIT cells. Adv Immunol (2015) 127:145-201. doi:10.1016/bs.ai.2015.03.003

2. Makino Y, Kanno R, Ito T, Higashino K, Taniguchi M. Predominant expression of invariant $\mathrm{V}$ alpha $14+\mathrm{TCR}$ alpha chain in NK1.1+ T cell populations. Int Immunol (1995) 7:1157-61. doi:10.1093/intimm/7.7.1157

3. Arase H, Arase N, Ogasawara K, Good RA, Onoe K. An NK1.1+ CD4+8single-positive thymocyte subpopulation that expresses a highly skewed T-cell antigen receptor V beta family. Proc Natl Acad Sci U S A (1992) 15(89):6506-10. doi:10.1073/pnas.89.14.6506

4. Kronenberg M, Gapin L. The unconventional lifestyle of NKT cells. Nat Rev Immunol (2002) 2(8):557-68. doi:10.1038/nri854

5. Lantz $\mathrm{O}$, Bendelac A. An invariant $\mathrm{T}$ cell receptor alpha chain is used by a unique subset of major histocompatibility complex class I-specific CD4+ and CD4-8- T cells in mice and humans. J Exp Med (1994) 1(180):1097-106. doi:10.1084/jem.180.3.1097

6. Lee PT, Benlagha K, Teyton L, Bendelac A. Distinct functional lineages of human V(alpha)24 natural killer T cells. J Exp Med (2002) 4(195):637-41. doi:10.1084/jem.20011908

7. Brigl M, Brenner MB. CD1: antigen presentation and T cell function. Annu Rev Immunol (2004) 22:817-90. doi:10.1146/annurev.immunol.22.012703.104608

8. Carreno LJ, Saavedra-Avila NA, Porcelli SA. Synthetic glycolipid activators of natural killer T cells as immunotherapeutic agents. Clin Transl Immunology (2016) 5:e69. doi:10.1038/cti.2016.14

9. Dellabona P, Abrignani S, Casorati G. iNKT-cell help to B cells: a cooperative job between innate and adaptive immune responses. Eur J Immunol (2014) 44:2230-7. doi:10.1002/eji.201344399

10. Hansen DS, Schofield L. Regulation of immunity and pathogenesis in infectious diseases by CD1d-restricted NKT cells. Int J Parasitol (2004) 34:15-25. doi:10.1016/j.ijpara.2003.09.007

11. Kharkwal SS, Arora P, Porcelli SA. Glycolipid activators of invariant NKT cells as vaccine adjuvants. Immunogenetics (2016) 68:597-610. doi:10.1007/ s00251-016-0925-y

12. Kohlgruber AC, Donado CA, LaMarche NM, Brenner MB, Brennan PJ. Activation strategies for invariant natural killer $\mathrm{T}$ cells. Immunogenetics (2016) 68:649-63. doi:10.1007/s00251-016-0944-8

13. Shimoda S, Tsuneyama K, Kikuchi K, Harada K, Nakanuma Y, Nakamura M, et al. The role of natural killer (NK) and NK T cells in the loss of tolerance in murine primary biliary cirrhosis. Clin Exp Immunol (2012) 168:279-84. doi:10.1111/j.1365-2249.2012.04581.x

14. Taniguchi M, Harada M, Kojo S, Nakayama T, Wakao H. The regulatory role of Valpha14 NKT cells in innate and acquired immune response. Annu Rev Immunol(2003)21:483-513.doi:10.1146/annurev.immunol.21.120601.141057

\section{ACKNOWLEDGMENTS}

The authors thank the NIH Tetramer Core Facility at Emory University, Atlanta, GA, USA, for providing PBS57-loaded CD1d tetramers and the Flow Cytometry Core Facility at the German Cancer Research Center for their support in cell sorting.

\section{FUNDING}

This work was supported by grants from the Deutsche Forschungsgemeinschaft (DFG) to H-JG and SP (SFB 938) and to H-JG (SFB 1118).

\section{SUPPLEMENTARY MATERIAL}

The Supplementary Material for this article can be found online at http://journal.frontiersin.org/article/10.3389/fimmu.2017.00848/ full\#supplementary-material.

15. Van Kaer L, Parekh VV, Wu L. Invariant natural killer $\mathrm{T}$ cells: bridging innate and adaptive immunity. Cell Tissue Res (2011) 343:43-55. doi:10.1007/ s00441-010-1023-3

16. Girardi E, Zajonc DM. Molecular basis of lipid antigen presentation by CD1d and recognition by natural killer T cells. Immunol Rev (2012) 250:167-79. doi:10.1111/j.1600-065X.2012.01166.x

17. Macho-Fernandez E, Brigl M. The extended family of CD1d-restricted NKT cells: sifting through a mixed bag of TCRs, antigens, and functions. Front Immunol (2015) 6:362. doi:10.3389/fimmu.2015.00362

18. Van Rhijn I, Godfrey DI, Rossjohn J, Moody DB. Lipid and small-molecule display by CD1 and MR1. Nat Rev Immunol (2015) 15:643-54. doi:10.1038/ nri3889

19. Porcelli SA, Modlin RL. The CD1 system: antigen-presenting molecules for T cell recognition of lipids and glycolipids. Annu Rev Immunol (1999) 17:297-329. doi:10.1146/annurev.immunol.17.1.297

20. Chiu YH, Park SH, Benlagha K, Forestier C, Jayawardena-Wolf J, Savage PB, et al. Multiple defects in antigen presentation and $\mathrm{T}$ cell development by mice expressing cytoplasmic tail-truncated CD1d. Nat Immunol (2002) 3:55-60. doi: $10.1038 /$ ni740

21. Gapin L. Development of invariant natural killer T cells. Curr Opin Immunol (2016) 39:68-74. doi:10.1016/j.coi.2016.01.001

22. Smiley ST, Kaplan MH, Grusby MJ. Immunoglobulin E production in the absence of interleukin-4-secreting CD1-dependent cells. Science (1997) 14(275):977-9. doi:10.1126/science.275.5302.977

23. Gapin L. iNKT cell autoreactivity: what is 'self' and how is it recognized? Nat Rev (2010) 10:272-7. doi:10.1038/nri2743

24. Honey K, Benlagha K, Beers C, Forbush K, Teyton L, Kleijmeer MJ, et al. Thymocyte expression of cathepsin L is essential for NKT cell development. Nat Immunol (2002) 3:1069-74. doi:10.1038/ni844

25. Salio M, Silk JD, Cerundolo V. Recent advances in processing and presentation of CD1 bound lipid antigens. Curr Opin Immunol (2010) 22:81-8. doi:10.1016/j.coi.2009.12.008

26. Zhou D, Cantu C III, Sagiv Y, Schrantz N, Kulkarni AB, Qi X, et al. Editing of CD1d-bound lipid antigens by endosomal lipid transfer proteins. Science (2004) 23(303):523-7. doi:10.1126/science.1092009

27. Kinjo Y, Ueno K. iNKT cells in microbial immunity: recognition of microbial glycolipids. Microbiol Immunol (2011) 55:472-82. doi:10.1111/ j.1348-0421.2011.00338.x

28. Kronenberg M, Kinjo Y. Innate-like recognition of microbes by invariant natural killer T cells. Curr Opin Immunol (2009) 21:391-6. doi:10.1016/j. coi.2009.07.002

29. Kawano T, Cui J, Koezuka Y, Toura I, Kaneko Y, Motoki K, et al. CD1d-restricted and TCR-mediated activation of valpha14 NKT cells by glycosylceramides. Science (1997) 28(278):1626-9. doi:10.1126/science.278.5343.1626 
30. Morita M, Motoki K, Akimoto K, Natori T, Sakai T, Sawa E, et al. Structureactivity relationship of alpha-galactosylceramides against B16-bearing mice. J Med Chem (1995) 9(38):2176-87. doi:10.1021/jm00012a018

31. Kinjo Y, Wu D, Kim G, Xing GW, Poles MA, Ho DD, et al. Recognition of bacterial glycosphingolipids by natural killer T cells. Nature (2005) 24(434):520-5. doi:10.1038/nature03407

32. Sriram V, Du W, Gervay-Hague J, Brutkiewicz RR. Cell wall glycosphingolipids of Sphingomonas paucimobilis are CD1d-specific ligands for NKT cells. Eur J Immunol (2005) 35:1692-701. doi:10.1002/eji.200526157

33. Kinjo Y, Tupin E, Wu D, Fujio M, Garcia-Navarro R, Benhnia MR, et al. Natural killer T cells recognize diacylglycerol antigens from pathogenic bacteria. Nat Immunol (2006) 7:978-86. doi:10.1038/ni1380

34. Kinjo Y, Illarionov P, Vela JL, Pei B, Girardi E, Li X, et al. Invariant natural killer T cells recognize glycolipids from pathogenic Gram-positive bacteria. Nat Immunol (2011) 12:966-74. doi:10.1038/ni.2096

35. Park SH, Benlagha K, Lee D, Balish E, Bendelac A. Unaltered phenotype, tissue distribution and function of Valpha14(+) NKT cells in germfree mice. Eur JImmunol (2000) 30:620-5. doi:10.1002/1521-4141 (200002)30:2<620::AID-IMMU620>3.3.CO;2-W

36. Cox D, Fox L, Tian R, Bardet W, Skaley M, Mojsilovic D, et al. Determination of cellular lipids bound to human CD1d molecules. PLoS One (2009) 4:e5325. doi:10.1371/journal.pone.0005325

37. Muindi K, Cernadas M, Watts GF, Royle L, Neville DC, Dwek RA, et al. Activation state and intracellular trafficking contribute to the repertoire of endogenous glycosphingolipids presented by CD1d [corrected]. Proc Natl Acad Sci U S A (2010) 16(107):3052-7. doi:10.1073/pnas.0915056107

38. Pei B, Speak AO, Shepherd D, Butters T, Cerundolo V, Platt FM, et al. Diverse endogenous antigens for mouse NKT cells: self-antigens that are not glycosphingolipids. J Immunol (2011) 1(186):1348-60. doi:10.4049/ jimmunol.1001008

39. Yuan W, Kang SJ, Evans JE, Cresswell P. Natural lipid ligands associated with human CD1d targeted to different subcellular compartments. JImmunol (2009) 15(182):4784-91. doi:10.4049/jimmunol.0803981

40. Gumperz JE, Roy C, Makowska A, Lum D, Sugita M, Podrebarac T, et al. Murine CD1d-restricted T cell recognition of cellular lipids. Immunity (2000) 12:211-21. doi:10.1016/S1074-7613(00)80174-0

41. Anderson BL, Teyton L, Bendelac A, Savage PB. Stimulation of natural killer T cells by glycolipids. Molecules (2013) 18:15662-88. doi:10.3390/ molecules181215662

42. Birkholz AM, Howell AR, Kronenberg M. The alpha and omega of galactosylceramides in T cell immune function. J Biol Chem (2015) 19(290):15365-70. doi:10.1074/jbc.R115.647057

43. Facciotti F, Ramanjaneyulu GS, Lepore M, Sansano S, Cavallari M, Kistowska M, et al. Peroxisome-derived lipids are self antigens that stimulate invariant natural killer T cells in the thymus. Nat Immunol (2012) 13:474-80. doi:10.1038/ni.2245

44. Stanic AK, De Silva AD, Park JJ, Sriram V, Ichikawa S, Hirabyashi Y, et al. Defective presentation of the CD1d1-restricted natural Va14Ja18 NKT lymphocyte antigen caused by beta-D-glucosylceramide synthase deficiency. Proc Natl Acad Sci U S A (2003) 18(100):1849-54. doi:10.1073/pnas. 0430327100

45. Brennan PJ, Tatituri RV, Brigl M, Kim EY, Tuli A, Sanderson JP, et al. Invariant natural killer $\mathrm{T}$ cells recognize lipid self antigen induced by microbial danger signals. Nat Immunol (2011) 12:1202-11. doi:10.1038/ni.2143

46. Brennan PJ, Tatituri RV, Heiss C, Watts GF, Hsu FF, Veerapen N, et al. Activation of iNKT cells by a distinct constituent of the endogenous glucosylceramide fraction. Proc Natl Acad Sci U S A (2014) 16(111):13433-8. doi:10.1073/pnas.1415357111

47. Yamashita T, Wada R, Sasaki T, Deng C, Bierfreund U, Sandhoff K, et al. A vital role for glycosphingolipid synthesis during development and differentiation. Proc Natl Acad Sci U S A (1999) 3(96):9142-7. doi:10.1073/pnas.96.16.9142

48. Jennemann R, Sandhoff R, Wang S, Kiss E, Gretz N, Zuliani C, et al. Cellspecific deletion of glucosylceramide synthase in brain leads to severe neural defects after birth. Proc Natl Acad Sci U S A (2005) 30(102):12459-64. doi:10.1073/pnas.0500893102

49. Lehuen A, Lantz O, Beaudoin L, Laloux V, Carnaud C, Bendelac A, et al. Overexpression of natural killer $\mathrm{T}$ cells protects Valpha14- Jalpha281 transgenic nonobese diabetic mice against diabetes. JExp Med (1998) 16(188):1831-9. doi:10.1084/jem.188.10.1831
50. Exley MA, Bigley NJ, Cheng O, Shaulov A, Tahir SM, Carter QL, et al. Innate immune response to encephalomyocarditis virus infection mediated by CD1d. Immunology (2003) 110:519-26. doi:10.1111/j.1365-2567.2003. 01779.x

51. de Boer J, Williams A, Skavdis G, Harker N, Coles M, Tolaini M, et al. Transgenic mice with hematopoietic and lymphoid specific expression of Cre. Eur J Immunol (2003) 33:314-25. doi:10.1002/immu.200310005

52. Rampoldi F, Bonrouhi M, Boehm ME, Lehmann WD, Popovic ZV, Kaden S, et al. Immunosuppression and aberrant $\mathrm{T}$ cell development in the absence of N-myristoylation. J Immunol (2015) 1(195):4228-43. doi:10.4049/jimmunol. 1500622

53. Porubsky S, Speak AO, Luckow B, Cerundolo V, Platt FM, Grone HJ. Normal development and function of invariant natural killer $\mathrm{T}$ cells in mice with isoglobotrihexosylceramide (iGb3) deficiency. Proc Natl Acad Sci US A (2007) 3(104):5977-82. doi:10.1073/pnas.0611139104

54. Chomczynski P, Sacchi N. Single-step method of RNA isolation by acid guanidinium thiocyanate-phenol-chloroform extraction. Anal Biochem (1987) 162:156-9. doi:10.1006/abio.1987.9999

55. Porubsky S, Jennemann R, Lehmann L, Grone HJ. Depletion of globosides and isoglobosides fully reverts the morphologic phenotype of Fabry disease. Cell Tissue Res (2014) 358:217-27. doi:10.1007/s00441-014-1922-9

56. Porubsky S, Speak AO, Salio M, Jennemann R, Bonrouhi M, Zafarulla R, et al. Globosides but not isoglobosides can impact the development of invariant NKT cells and their interaction with dendritic cells. J Immunol (2012) 15(189):3007-17. doi:10.4049/jimmunol.1201483

57. Saito M, Kasai N, Yu RK. In situ immunological determination of basic carbohydrate structures of gangliosides on thin-layer plates. Anal Biochem (1985) 148:54-8. doi:10.1016/0003-2697(85)90627-X

58. Rabionet M, van der Spoel AC, Chuang CC, von Tumpling-Radosta B, Litjens M, Bouwmeester D, et al. Male germ cells require polyenoic sphingolipids with complex glycosylation for completion of meiosis: a link to ceramide synthase-3. J Biol Chem (2008) 9(283):13357-69. doi:10.1074/jbc. M800870200

59. Jennemann R, Kaden S, Sandhoff R, Nordstrom V, Wang S, Volz M, et al. Glycosphingolipids are essential for intestinal endocytic function. J Biol Chem (2012) 21(287):32598-616. doi:10.1074/jbc.M112.371005

60. Porubsky S, Wang S, Kiss E, Dehmel S, Bonrouhi M, Dorn T, et al. Rhoh deficiency reduces peripheral $\mathrm{T}$-cell function and attenuates allogenic transplant rejection. Eur J Immunol (2011) 41:76-88. doi:10.1002/eji. 201040420

61. Griewank K, Borowski C, Rietdijk S, Wang N, Julien A, Wei DG, et al. Homotypic interactions mediated by Slamf1 and Slamf6 receptors control NKT cell lineage development. Immunity (2007) 27:751-62. doi:10.1016/j. immuni.2007.08.020

62. Benlagha K, Kyin T, Beavis A, Teyton L, Bendelac A. A thymic precursor to the NK T cell lineage. Science (2002) 19(296):553-5. doi:10.1126/science. 1069017

63. Wei DG, Curran SA, Savage PB, Teyton L, Bendelac A. Mechanisms imposing the Vbeta bias of Valpha14 natural killer T cells and consequences for microbial glycolipid recognition. J Exp Med (2006) 15(203):1197-207. doi:10.1084/ jem. 20060418

64. Gadola SD, Silk JD, Jeans A, Illarionov PA, Salio M, Besra GS, et al. Impaired selection of invariant natural killer T cells in diverse mouse models of glycosphingolipid lysosomal storage diseases. J Exp Med (2006) 2(203):2293-303. doi:10.1084/jem.20060921

65. Darmoise A, Teneberg S, Bouzonville L, Brady RO, Beck M, Kaufmann SH, et al. Lysosomal alpha-galactosidase controls the generation of self lipid antigens for natural killer $\mathrm{T}$ cells. Immunity (2010) 27(33):216-28. doi:10.1016/j.immuni.2010.08.003

66. Brites P, Waterham HR, Wanders RJ. Functions and biosynthesis of plasmalogens in health and disease. Biochim Biophys Acta (2004) 22(1636):219-31. doi:10.1016/j.bbalip.2003.12.010

67. Kain L, Webb B, Anderson BL, Deng S, Holt M, Costanzo A, et al. The identification of the endogenous ligands of natural killer $\mathrm{T}$ cells reveals the presence of mammalian alpha-linked glycosylceramides. Immunity (2014) 16(41):543-54. doi:10.1016/j.immuni.2014.08.017

68. Sprong H, Degroote S, Claessens T, van Drunen J, Oorschot V, Westerink BHC, et al. Glycosphingolipids are required for sorting melanosomal proteins in the Golgi complex. J Cell Biol (2001) 155:369-80. doi:10.1083/jcb.200106104 
69. Stone JD, Chervin AS, Kranz DM. T-cell receptor binding affinities and kinetics: impact on T-cell activity and specificity. Immunology (2009) 126:165-76. doi:10.1111/j.1365-2567.2008.03015.x

70. Sykulev Y, Joo M, Vturina I, Tsomides TJ, Eisen HN. Evidence that a single peptide-MHC complex on a target cell can elicit a cytolytic T cell response. Immunity (1996) 4:565-71. doi:10.1016/S1074-7613(00)80483-5

71. Mallevaey T, Clarke AJ, Scott-Browne JP, Young MH, Roisman LC, Pellicci DG, et al. A molecular basis for NKT cell recognition of CD1d-selfantigen. Immunity (2011) 25(34):315-26. doi:10.1016/j.immuni.2011.01.013

72. Mallevaey T, Selvanantham T. Strategy of lipid recognition by invariant natural killer T cells: 'one for all and all for one'. Immunology (2012) 136:273-82. doi:10.1111/j.1365-2567.2012.03580.x

73. Inokuchi J, Nagafuku M, Ohno I, Suzuki A. Distinct selectivity of gangliosides required for CD4(+) T and CD8(+) T cell activation. Biochim Biophys Acta (2015) 1851:98-106. doi:10.1016/j.bbalip.2014.07.013
74. Zhou D, Mattner J, Cantu C III, Schrantz N, Yin N, Gao Y, et al. Lysosomal glycosphingolipid recognition by NKT cells. Science (2004) 3(306):1786-9. doi:10.1126/science. 1103440

Conflict of Interest Statement: The authors declare that the research was conducted in the absence of any commercial or financial relationships that could be construed as a potential conflict of interest.

Copyright (c) 2017 Popovic, Rabionet, Jennemann, Krunic, Sandhoff, Gröne and Porubsky. This is an open-access article distributed under the terms of the Creative Commons Attribution License (CC BY). The use, distribution or reproduction in other forums is permitted, provided the original author(s) or licensor are credited and that the original publication in this journal is cited, in accordance with accepted academic practice. No use, distribution or reproduction is permitted which does not comply with these terms. 